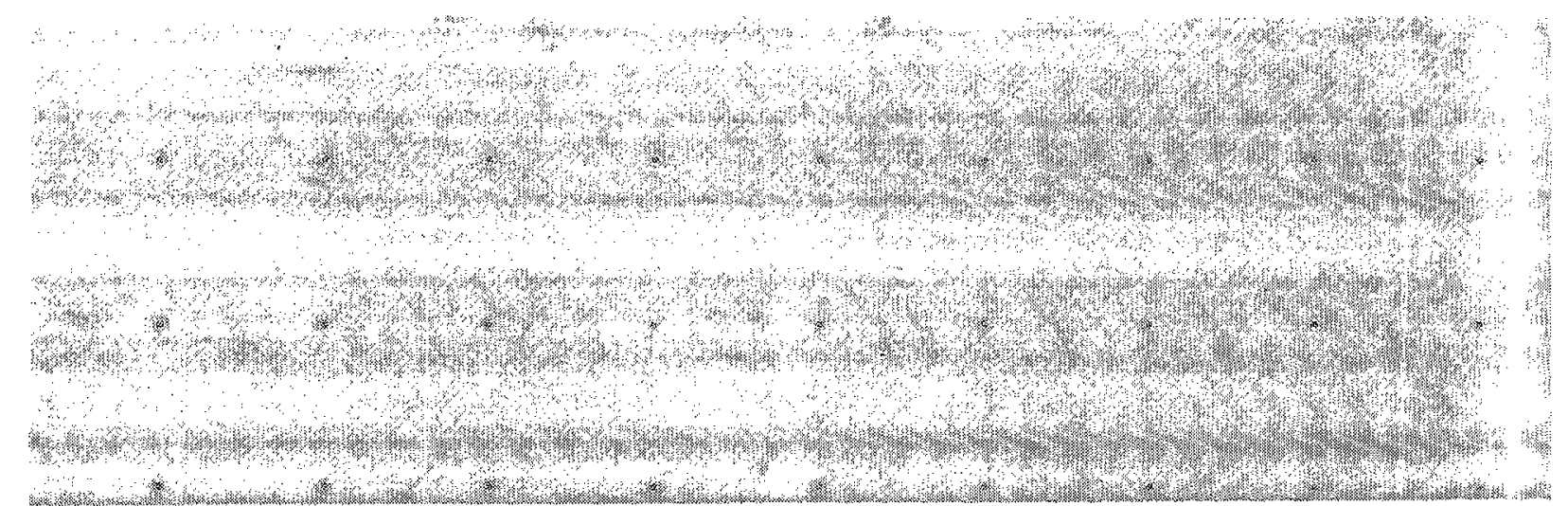

\title{
RITUAL AND ENVIRONMENT: THE MOSIT CEREMONY OF THE ETHIOPIAN ME'EN PEOPLE
}

BY

\author{
JON ABBINK \\ (University of Nijmegen and African Studies Centre, Leiden, The Netherlands)
}

\section{Introduction}

This essay deals with the problem of the relation between ritual behaviour and environmental conditions in an African rural society. Many studies in anthropology/ethnology have been devoted to the inter-relationship of these two spheres, especially by proponents of the 'ecological anthropology'-school, but also by those favouring a more social-structural, symbolic or cognitive approach to ritual life. The present study will try to integrate the 'ideational' and the material-environmental elements, in order to explain how meaning in ritual is constituted in the dialectic between human action and environmental conditions.

For this purpose, a text of the mósit, a central ritual of the Me'en people, a lesser-known group of South-East Surmic (Nilo-Saharan) speakers in Southwestern Ethiopia ${ }^{1}$ will be presented and discussed. It will be analysed as part of the action structure of the ritual as a whole, placed in its cultural context.

The Me'en people have only had marginal contacts with (Ethiopian Orthodox) Ghristianity (none with organized Islam) and provide an interesting and perhaps amazing example of how a 'traditional' local religion has maintained itself. They live in a relatively remote region of Africa, where the cultural effects of 'globalisation' and political-economic and cultural incorporation into state or wider institutional structures-often seen as already being universal in the Third World-are still marginal.

In the following analysis of the ritual, I will look at the significance of environmental referents in the ritual acts and words, and at how the language and the context of the mosit reflect social and reproductive relations within Me'en society. The first point 


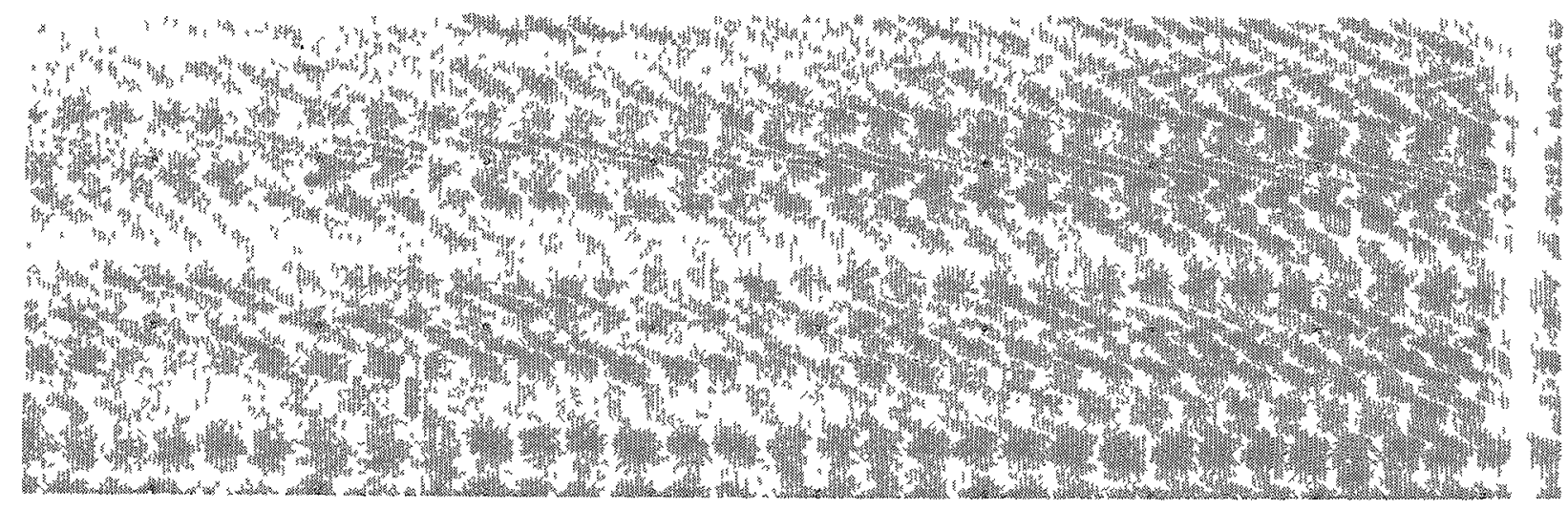

will be highlighted on the basis of presentation of the text said at the occasion of this ritual. The second point departs from these textclues to extend the analysis to the social and environmental context. The aim is an explanatory account of the mósit as a religious ritual system. The unifying theoretical perspective which informs this analysis is derived from the theory of Lawson and McCauley 1990, an important study which has advocated a 'competence'-approach to religious ritual behaviour.

The theory of ritual, while always a central subject in comparative philosophical-religious studies and in anthropology, has made great strides in recent years. On the basis of earlier Durkheimian theories emphasizing the social integrative functions of ritual, formal and socio-ecological systems approaches have been developed (Rappaport 1979, 1984), as well as the influential symbolic theories in the vein of $V$. Turner $(1967,1969,1977)$. More recent views on ritual have moved towards explanation of its double aspect of cognitive-ideological structure and motivated, strategic social drama. Analysis of its modes of discourse has also become central (e.g., Barth 1975, Lewis 1980, Strecker 1988, Keesing 1990), and has clarified much about the socio-cultural basis on which the cognitive human predispositions for ritual performance are expressed. A recent survey on ritual studies by W. Doty (1992) concludes that there is a tendency less to grand theorizing (p. 118) than toward descriptions and actual ritual behaviour (p. 125). While one can readily agree with this view, the question is whether this trend is beneficial or not, and whether theories of the middle range do not deserve to be developed and tested.

The present study contains an attempt toward such a theoretically inspired explanation of the mósit ritual, spurred by some recent work on the border-line of cognitive and religious studies. The theoretical approach to ritual followed in the present paper could thus be described as a broadly 'cognitive' one. This holds in a double sense. First, ritual, as part of a symbolic-cultural system, can be seen as a specific human way of dealing with and relating to a (human and natural) environment to be acted upon for purposes of understanding, establishing 'meaning' and achieving a measure of 'control' in an initially neutral or ambiguous world. This view is reminiscent of the 'neo-intellectualist' theory of religious systems (cf. Guthrie 1980, 1993). But while this theory highlights one relevant aspect, it does not offer a fully satisfactory 


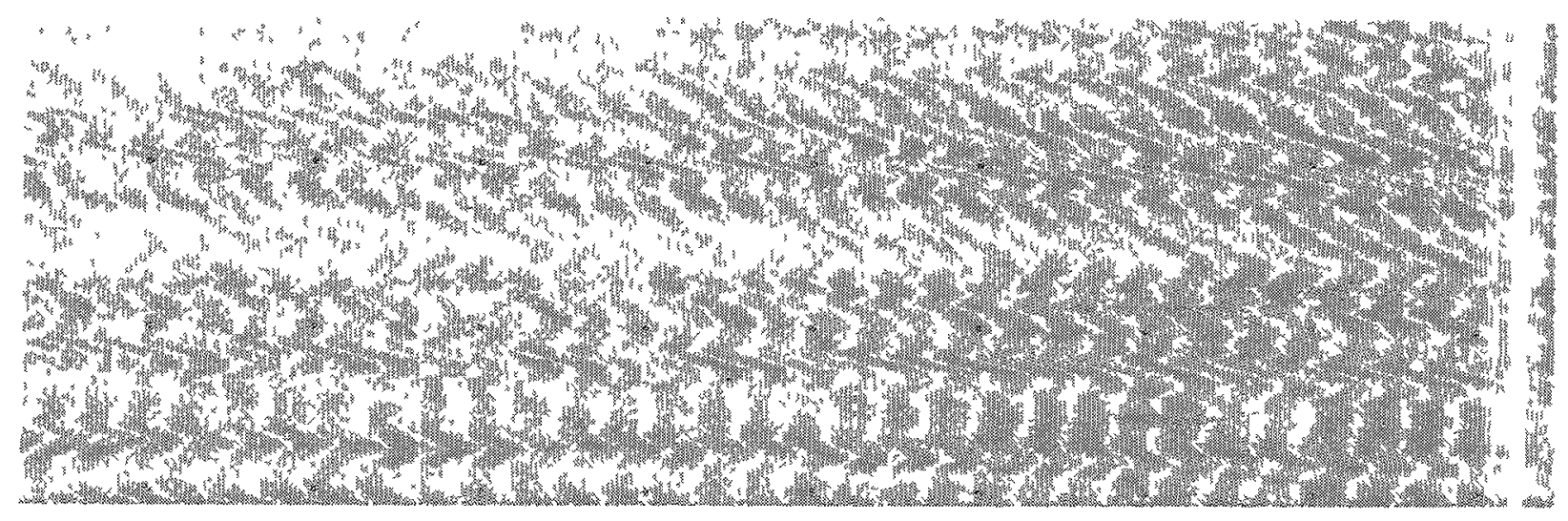

account of religious ritual, not all aspects of which can be said to have an 'explanatory' dimension referring to empirical reality (cf. Lawson \& McCauley 1990: 36-37, 156). A broader conception of the cognitive process, denoting formal, psychologically-rooted mechanisms of humans to produce and process representation, defines the pattern of religious behaviour in conjunction with the religious conceptual system, and tries to trace its workings as part of an overall meaningful pattern generated by actions following certain predictable formal procedures. Ritual acts are taken as the basic building blocs, which reveal generative patterns. This approach has been offered by Lawson \& McGauley, who have developed their challenging theory of religious ritual competence in analogy to the theory of language competence (Lawson \& McCauley 1990: 77). A central part of their theory is, therefore, the analytic description of ritual acts. The acts have action structures. Explicating their conditions and their structural character yields an explanatory description of religious ritual (cf. Lawson \& McCauley 1990: 85, 121, 174-175). The claim in this article is not to exhaustively explain the Me'en world-view but to sketch the basic conditions for this, elucidating its structure and cultural context and indicating some of the dominant concerns which inform the specific relationship which these people entertain with their environment.

\section{Delineating Ritual}

As we know, a comprehensive description or definition of the phenomenon of 'ritual' is not easy to give, nor is it fruitful to elaborate at length on the definitional problem. When studying ritual in non-literate, small-scale rural societies such as the Me'en, it is often striking that there is usually no specific word for 'ritual' or 'ritual activity'. This does not prevent outside observers from quickly recognizing it, however. As Lewis (1980: 6) says: '.. sometimes we feel almost sure that something is ritual before we know or can think of any meaning for it.' What is the reason for this? Is it the bias of observers from a literate, hierarchical society where rituals-especially collective, society-wide rituals-have been declining or have lost their 'credibility', a fact which makes them note ritual behaviour in other, presumably more integrated societies? Part of the answer may be that rituals in a small-scale 


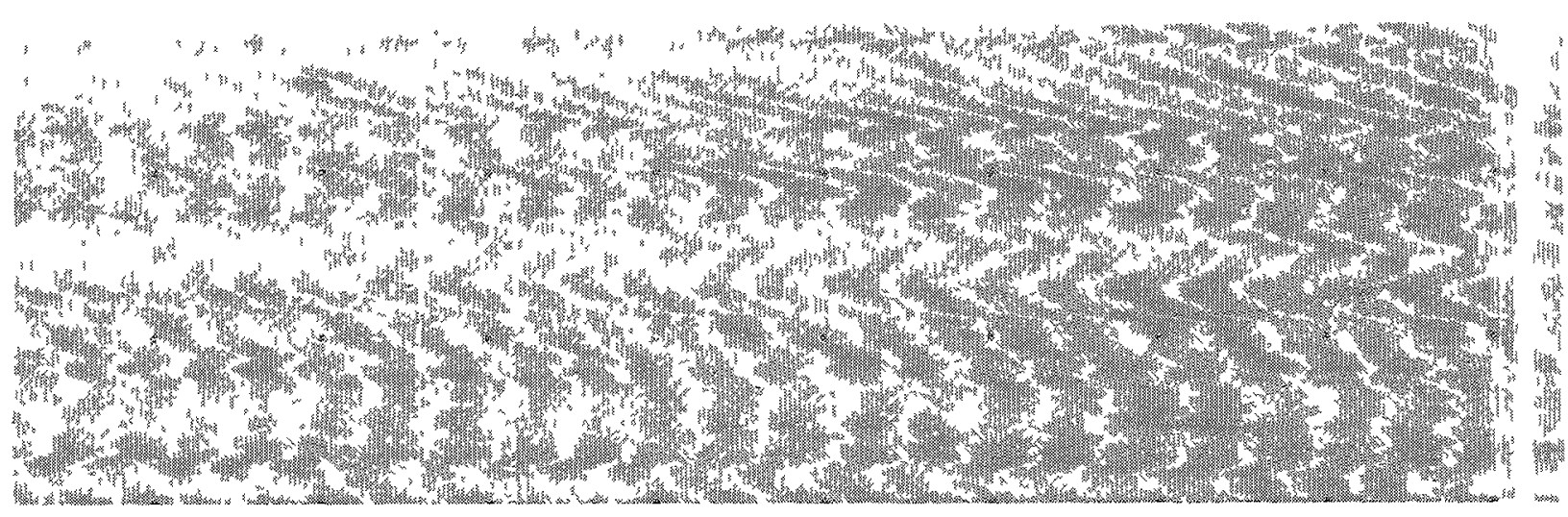

society-and originally probably in every human society-are indeed a vital and often dominant focus of group life, bound up with notions of social and cosmological order perceived or pursued by that specific society. Rituals codify a world-view and permit the acting out of ideological assumptions of collective life in a formal, model-like manner. They emerge in the dialectic of language and action. Rappaport (1979a: 174), in a challenging analysis of the formal properties of ritual action, even states that ritual is '... the basic social act.' Devoting chief attention to the structure of ritual (and not primarily to its 'symbolism'), he has stressed the elements of 'social contract' and of 'morality' which may emerge from it. This point would be especially relevant for (religious) rituals in the non-literate non-industrial societies where anthropologists have done most of their work.

On a somewhat more abstract level, Lawson \& McCauley (1990: 77) have pointed to the fact that '... participants in religious ritual systems possess ... intuitive insight into the character of ritual acts.' Like that of speakers about their language, this intuition reflects mastery of a body of knowledge about cultural systems (beyond the level of the individual). Participants in a ritual have many of the requisite intuitions about ritual form, and have '...knowledge about the acceptability of ritual performances.' (ibid.). Thus, ritual gives evidence of shared knowledge, partly held unconsciously and the result of learning but not instruction. It is intuitively applied by participants during a ritual. This means that there is a 'competence', which goes back to principles of operation of the human conceptual apparatus. We see here the cognitive foundation of their theory, inspired by generative linguistics.

In the literature, some recurring necessary conditions for a public activity to be called ritual can be found (see e.g., Rappaport 1979a: 175-177; Keesing 1990: 64-65):

* it is a public, explicit act or series of acts

* it involves stylized, conventionalized behaviour in word and action

* it is a kind of performance, a drama with a 'script', not made by the participants on the spot, but inherited from the past, from the 'ancestors', and the constraints of which are known

* it has to do with central concerns of the community in which the ritual has emerged

* it has (auto-)communicative aspects, relevant to the 'audience' as well as to the 'performers' themselves. 


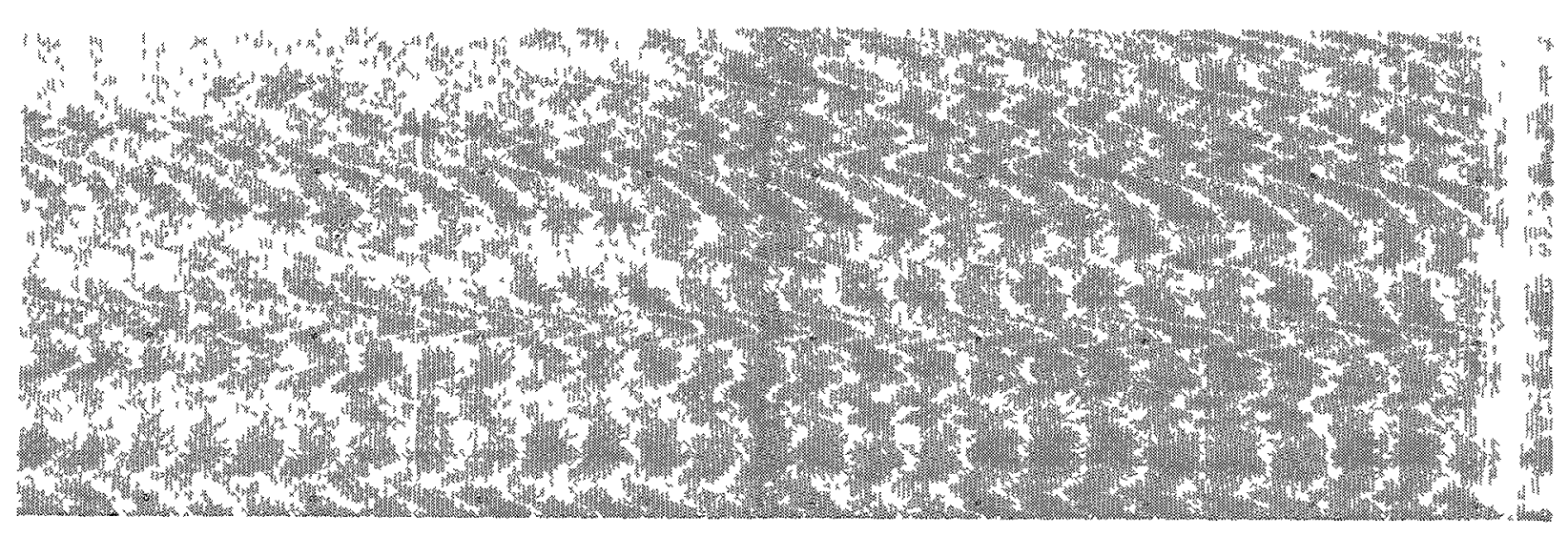

These conditions suggest that ritual, in a descriptive sense, is a staged social performance with repetitive acts and formulas appealing to central tenets or 'commitments' of the culture within which it is recognized. The emotionally evocative aspect of ritual has been emphasized in several theories of ritual and is indeed present by virtue of its dramatic form. But the evocation of emotion or sentiments is not a purpose of ritual per sé. In line with our cognitive approach to ritual, we see the emotional appeal of ritual as a by-product, not an end in itself, of the human effort to render the world meaningful or manageable.

In many definitions of ritual (e.g. Rappaport's 1979b: 28), a reference to the 'supernatural' is included. While assumptions about non-human or super-human agents are usually relevant, this concept of supernatural as opposed to the natural of the human may not always be necessary. Guthrie (1980: 185) has noted that the 'supernatural' is a western folk category, resulting from the humans-nature opposition found in the Greco-Christian tradition, and it may already reflect a particular assumption concerning the relationship between humans and the 'environment'. If applied without reflection, one may miss the specific conception of this relationship in the culture under study. This relationship has to be clarified first before one can assess its practical implications or its possibilities for change. Lawson \& McCauley (1990: 7), however, speak of religious ritual as a part of a wider religious conceptual system whereby assumptions about 'culturally postulated superhuman agents' are always important: such assumptions indeed differentiate religion from any other systems of belief.

\section{Humans and Nature: Context of the Mósit Ritual}

\section{The Environment and Its 'Perception'}

Important to note is that the relation between humans and nature should not be seen dualistically. T. Ingold (1993: 40), in his brief but excellent article on culture and environment, pleads for a 'mutualistic' view: in the course of their practical activities in relation to their environment, people acquire a direct (practical) knowledge of it, without first 'constructing' or fully understanding or knowing it in all implications (ibid.: 52). Perception of the environment (by animals as well as humans) is not prior to utilizing it. 


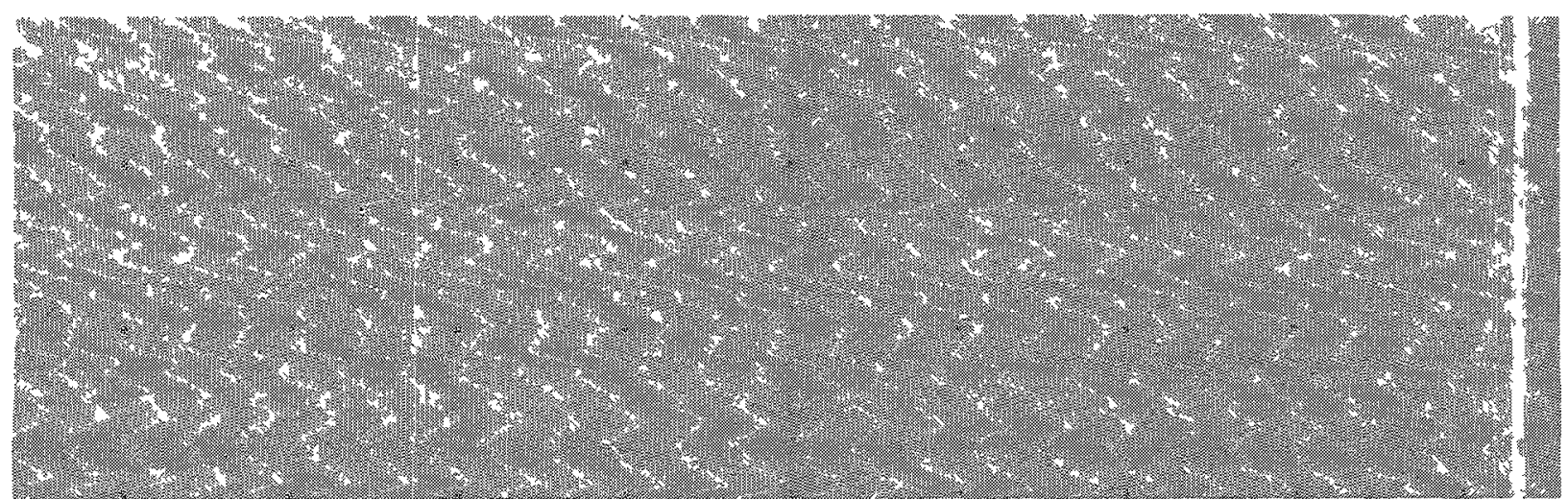

The environment is immediately apprehended or interpreted in the course of life activities (and thus not "really to be"seen as separate or opposed). It is seen by humans in terms of what it affords them in relation to the activities in which they are engaged.

While this view of 'affordances' of the environment is extremely useful for a sound theory of the relation between humans and environment and as an antidote to an in many ways spent 'cultural constructivist' approach, one aspect remains a bit understated in Ingold's analysis: that of humans entering into planned, long-term emgagement with the environment. The manner of engagement will over time become part of collective human behaviour enhancing the chances of humans in that same life process, and is a manner which will become 'culture'. Religious ritual is one of the cultural mechanisms by which this is achieved.?

As will become clear, these arguments are relevant in considering the mósit ritual, which is a seasonal ritual held just before the main harvest and consumption of the staple crops maize or sorghum. By enacting it, the Me'en express an intimate relation with their environment and with the inanimate and animate beings which they have to deal with. Doing the ritual, one might say, is part of how they utilize the environment, or of how they engage it (cf. Ingold 1993: 44).

\section{The Me'en}

The Tishana-Me'en people (numbering ca. 50,000 in 1991) are a group of 'tribal' cultivators in the Southwest of Käfa Region, in a fairly isolated area of Ethiopia They have often been qualified as 'Nilotic' people, but while they have some cultural practices fitting the 'Nilotic' profile of e.g. Nuer or Dinka, this epithet is misleading. They neither have a Nilotic language nor a predominantly pastoral way of life. The Tishana-Me'en practice shifting cultivation (maize, sorghum, some teff, barley, lentils and beans), animal husbandry, and do some hunting and gathering. ${ }^{3}$ In the late 19th and early 20th century, they were more of a cattleherding people. Nowadays, they are mostly cultivators, but their mobility is great. Fields are changed very frequently, and the location of homesteads every year changes accordingly, although one often remains within the confines of a (shifting) ancestral clan territory. There are no Me'en villages. Trade is not significant: the 


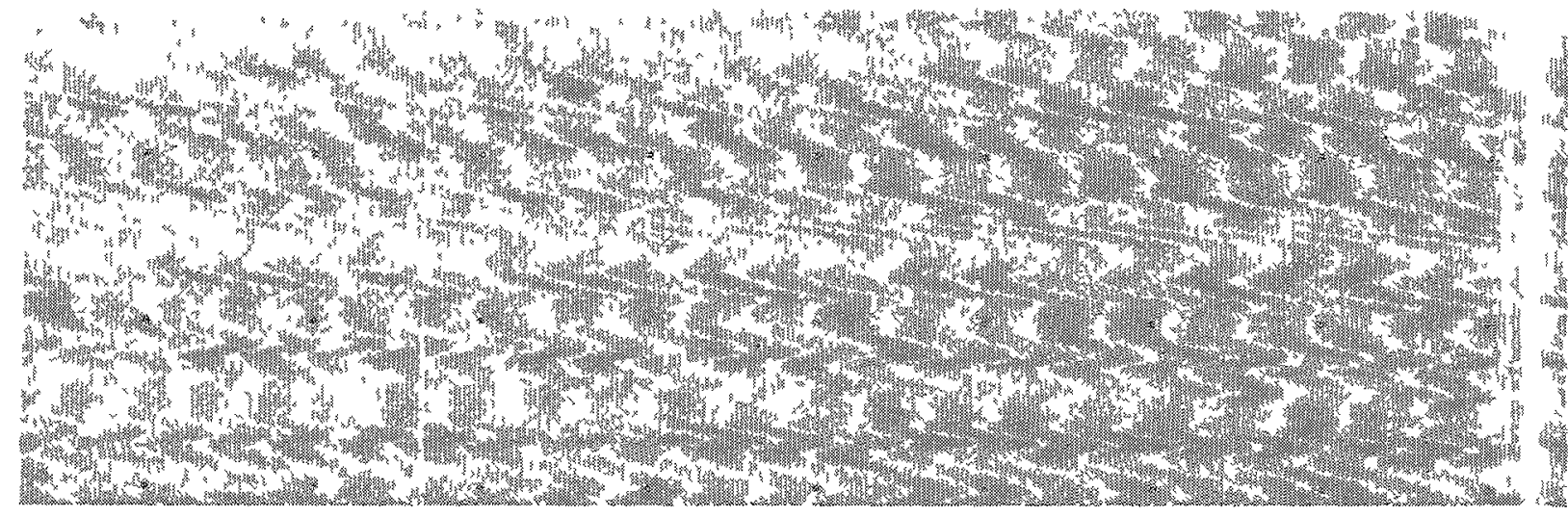

Me'en produce no big export crops except some coffee, bought up by non-Me'en traders for transport to regional market centers like Mizan Täfäri or Jimma. The level of technology and environmental control is low. Their region is not well-integrated into the wider Ethiopian society. Labour migration by $\mathrm{Me}$ 'en is virtually nonexistent. There are no public facilities, like transportation, agricultural extension programs, credit facilities, shops, nor even welldeveloped regional markets in the area. There is only a handful of primary schools. Knowledge of Amharic or any other Ethiopian language besides their own Me'en language is limited. Only on the northern and southern fringes of the Me'en area, where (Omoticspeaking) Bench and Dizi people are found respectively, the Me'en also speak the language of the neighbouring group. Their economy is predominantly geared to subsistence. Apart from the proceeds from coffee sales, occasional cash money is only found by selling livestock or honey in the five kätämas located in the Me'en area (i.e., the original settler-villages founded by northerners in the early years of this century). Agricultural work in the corn and sorghum fields is mostly collective: work-teams composed of relatives and neighbours clear, burn off and (sometimes) weed the fields, and haut in the crop at harvest time. The sorghum or maize beer (sholu) distributed at collective work-parties is prepared by women. During the growing of the crops, women are responsible for the fields, and also for the gardens near the homesteads, and for petty trade of foodstuff, milk or local beer. They may own some small stock or cattle, but less than the men. The socio-economic and kinship role of women is in many ways central to Me'en social life, although they do not figure in leading public roles such as komorut, acting clan/lineage head, raider, or diviner.

Me'en social structure is segmented. People are usually identified by membership in nominal patrilineal lineage- or 'clan'groups. Community leaders are the elders, especially those from certain old clans. The former 'rain chiefs' (komorut) of the Me'en have lost most of their influence, though they are still important as mediators, e.g. in homicide compensation settlements.

The impact of the state-socialist policies of the former MarxistLeninist government of Ethiopia (1975-1991) has not been beneficial, either politically, or economically or culturally. Traditional religious and ritual beliefs and practices were devalued, discouraged and sometimes prohibited, and much ritual property 


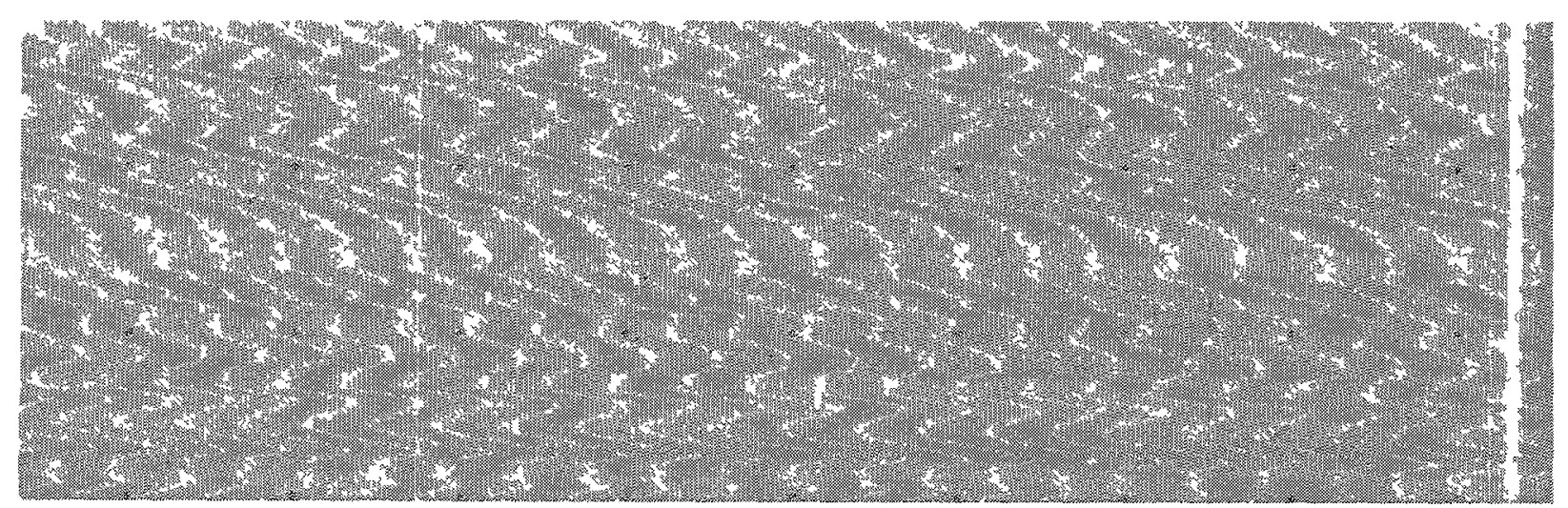

was confiscated or destroyed outright. The worst effects were felt during the violent students' zämächa campaign (1977-78), but continued also after that. Many young people were forcibly drafted into the national army to fight in the civil war in the north and did not return.

In the days when the $\mathrm{Me}^{\prime}$ en were still predominantly agropastoralists in the Shorum and Omo River valleys (in the mid-19th century; cf. Abbink 1990), their main crop was sorghum. Nowadays, in the highland setting, it is maize. Compared to sorghum, maize perhaps gives a larger yield per unit of cultivated land and labour input. It is also much preferred by the $\mathrm{Me}^{\text {'en for }}$ its sweeter taste. But once stored, it is probably more vulnerable to various insect pests (e.g., weevils) and to rats than sorghum. During its growth on the fields, maize may not run more risks from animal pests than sorghum, but it is much less drought-resistant. Sorghum thus remains an indispensible food crop. In former times, the Me'en performed their main mósit ceremony (described by Tippett 1970: 89f. as a 'first fruit ceremony') for sorghum, as it is still done by the Bodi-Me'en and by the agro-pastoral Suri people west of Maji, a group with notable historical and linguistic affinities with the Me'en. Today, the Tishana-Me'en (living mainly in an intermediate highland zone, between c. 1100 and $1800 \mathrm{~m}$.) hold the ceremony predominantly for maize, because it is by far their most important staple crop, and, as said, is seen as vulnerable. If the maize-crop fails, there is hunger in the Me'en area, and external aid in such a case is rare.

\section{The Wider Religious Conceptual System of the Me'en}

As Lawson \& McCauley noted (1990: 7, 87), religious ritual must be viewed in its connection with the religious conceptual scheme of which it is a logical part. A system of representations in the conceptual sphere is reflected in ritual action. The Me'en religious conceptual system is perhaps not elaborate but has several connected domains: a) belief in the Sky-God Tuma, who is the source of rain, fertility, growth and cosmic order; b) belief in the presence or importance of lineage and ancestors, often collectively referred to as $k^{\prime}$ 'alua, the 'spirit' of the descent line of a person which may manifest itself in dreams; c) the local spirits or forces, called k'olle; and d) recourse to spirit-possession and healing, by specialists 


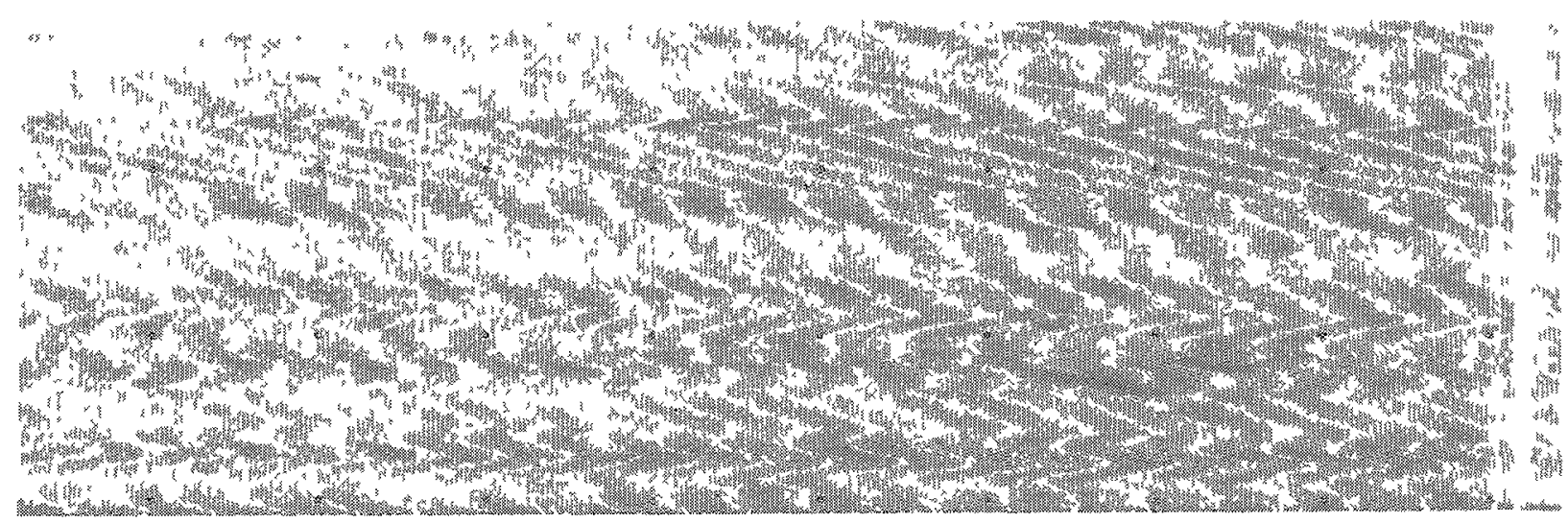

called men-de-nyerey. As especially the last part (spirit possession) is demonstrably a more recent (early and mid-twentieth century) accretion to the religious system of the Me'en, it is not always clear, either to observers or to Me'en themselves, in what way the various domains interlock or are mutually interdependent in a conceptual sense. It may be said that the first two points form the 'core' of the Me'en world-view, but the latter two parts are pragmatically being integrated into it. ${ }^{4}$ There is no cult of the creator-god (Tuma)-in line with many other African 'tribal' religions-and neither one of the 'ancestors': sacrifices or offerings are not made to them. They are appealed to, and may be seen as 'agents' whose influence can be felt at critical moments. But they are otherwise not held to be much involved in day-to-day life. A fifth domain which might possibly be considered one of religious or superhuman character is that of divination and magic, done in a variety of ways by certain experts (see e.g. Abbink 1993): entrail-reading, divination of water patterns on cattle-skin, and of bird sounds and movements. But neither here is a connection with Tuma or the 'ancestors' established. As in religious activities, a concern with solving practical and daily problems within the context of the wider community and environment stands central, but divination can only be marginally considered as part of the religious conceptual system; for example in divination on the basis of animal entrails, there is no offering to or invocation of God or ancestors.

Finally, it may be important to note that in this society of segmented groups and hereditary ritual 'chiefs', religious ritual life is not an arena for political power struggles. ${ }^{5}$

\section{Place of the Mósit Rituals in the Religious Conceptual System}

The mósits are important in that they represent one of the few full-scale, annually held, group ceremonies in Me'en society. Mósit is actually the term used for various rituals performed by Me'en. The word itself literally refers to 'fire-making with wooden sticks', one twirled around in the other to produce smouldering ashes caught in fine grass, which are then blown into a fire. The act of producing the fire is hak-mósit, i.e. the 'hitting of the firesticks'. The control and use of fire (guó) is of course a crucial element in this shifting-cultivator society: for burning the fields, and for preparation of nearly all food. It is also an icon for the peaceful 


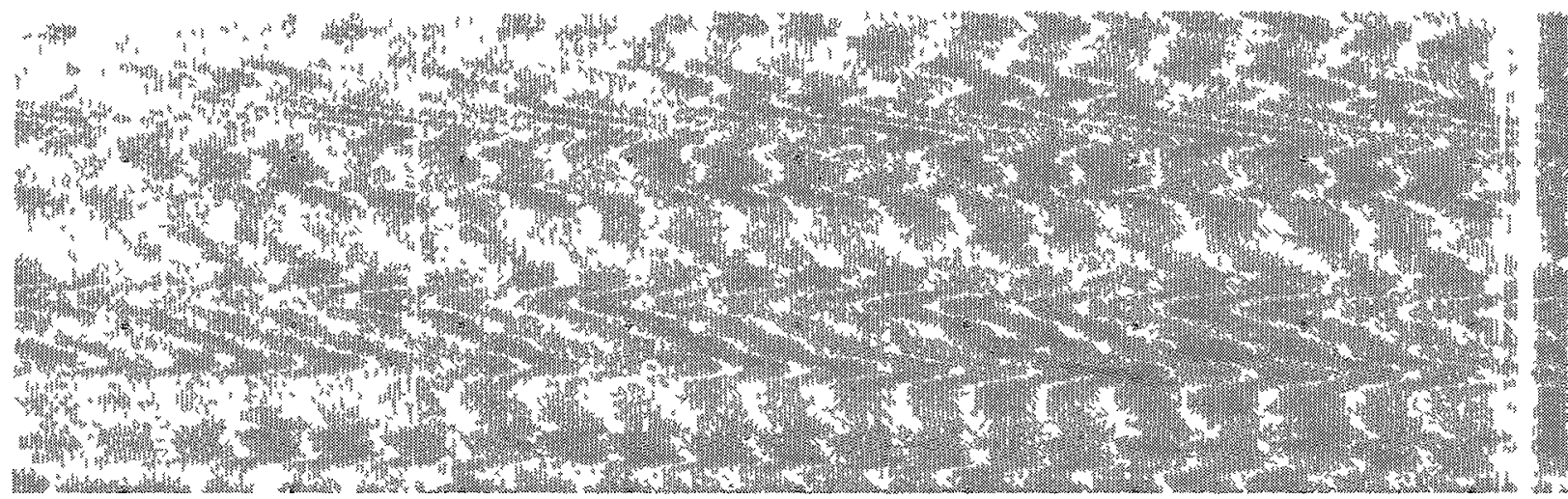

homestead, with a fire-place (bakut) in the centre. One migration myth of the Tishana-Me'en tells of the near loss of fire when they crossed the P'ada River (i.e., the Omo) and its last-minute recovery by a dog, who swam back to the 'homeland' across the river, lighted his tail, and then gave the fire to the migrants. In the past, the Me'en more commonly held mósits for cattle, for the honey 'harvest' from their beehives, and even for (or better, against) malaria. This already suggests that the ritual may have to do with protection, with ensuring a beneficial development of the beings for which the fire and its smoke are made. Also, according to informants, the completion of the ritual signified that all people could start to harvest and consume the new crop. In the religious structure of the Me'en as a whole the mósits are undoubtedly a central element. Rituals of this kind are present among other East African agro-pastoral groups, but have so far not really been described or considered in their wider religious context. ${ }^{6}$

In the ritual of the mósit, there is a connection with the powers of the Sky-God Tuma, and of the lineage spirits or 'ancestors', though it does not seem to be predominant in the text and the acts to be presented below. The connection with the Sky-God may well have been the original religious referent of the mósit, but has been obscured by the emphasis on divination and magic, and on the clan and lineage ancestors, a result of the 'localization' of these groups: there is a tendency to become more sedentary in the wake of an emerging specialization in cultivation, by population growth, and by more dependency on relations with neighbouring groups like the Bench and Dizi.

The mósit, however, still is a core ritual, epitomizing the Me'en way of life in a socio-economic and religious sense. This becomes clear in considering the spatial, social, seasonal and ideological aspects of its setting. In what follows, a first overview of the Me'en mósit-ritual will be given and its structure analysed. Its place in the larger scheme of Me'en religious ideas will be clarified.

\section{The Setting}

The setting for the ritual comprises objects, participants and a chosen place and time.

a) Objects. Every Me'en mósit requires a set of ritual paraphernalia in order to be carried out properly: 


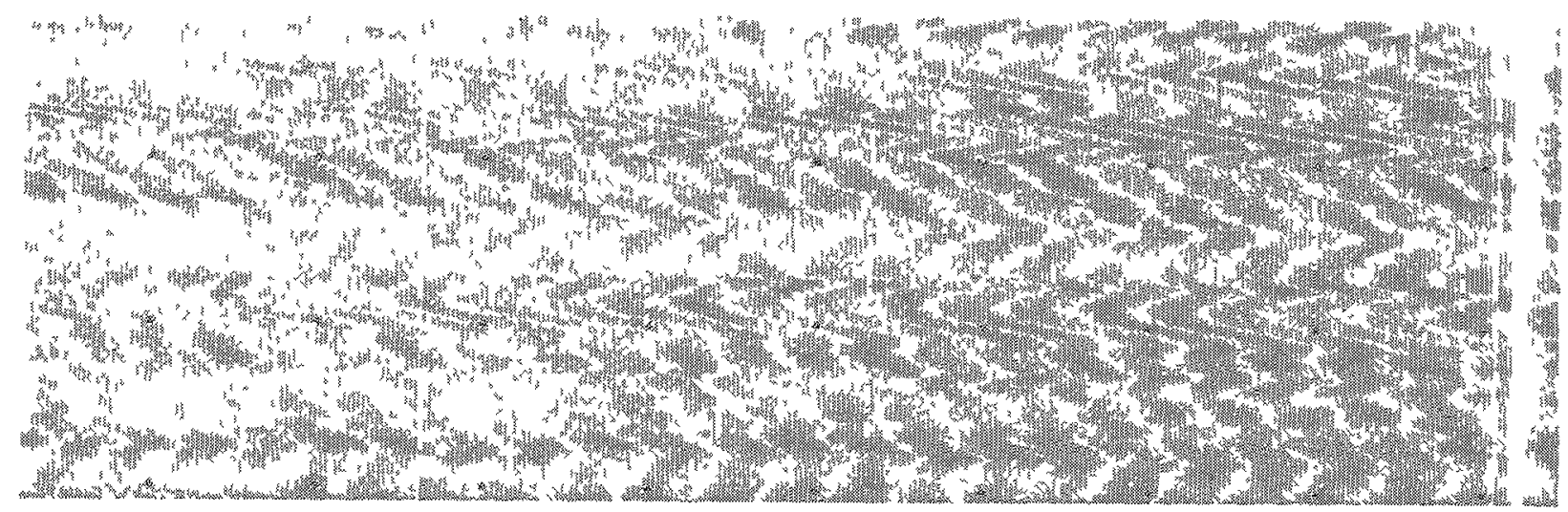

1. the fire-sticks, made from tulmit wood (an as yet undetermined plant species, probably Trichilia emetica Forsk.)

2. a bundle of fine-leafed grass, called habay de kanggaji or 'baboongrass' (undetermined species)

3. branches of a plant called jakach (Maytenus senegalensis (Lam.) Exell.)

4. branches of a plant called latech (Terminalia Orbicularis Engl. \& Diels.)

5. branches of a plant called chubulukuni (Osiris lanceolata Hochst. ex Steudel)

6. lumps of fine reddish earth or clay taken from a termite hill, called b'akadech

7. a black round basalt stone (bèto-de-koroy)

8. coffee leaves (sáliche-tikáy, bunt'ula).

These natural objects are essential for any complete mósit-ritual, and great pains are taken, days in advance, to collect them and bring them to the place of the ceremony. All plant materials as well as the black stone come from the lowland area (kóru) near the Shorum River. Sometimes, a substitute can be used for plants: e.g. for chubulukuni one may take the round fruit (called burách) of the Oncoba spinosa tree, also a tough lowland species. These various plants (except the tulmit) are seen as having 'power' above that of other plants. Goffee (made from the leaves) always was ritual drink among the Me'en, and not drunk daily.

b) Participants. There are four main 'actors' staging the ritual, who are elder members of three or four different Me'en 'clans'.' They are divided in two pairs of a male and a female partner ${ }^{8}$ although the actual sex of the actors usually is male. The partners of each pair stand in a relationship of 'kokó' to each other. This means that they are each other's 'ritual assistants', coming from opposing, marriageable clan-groups. One of these four officiating people has to be a member of an old Me'en-chim ( = 'definitely' or 'real' Me'en) clan, i.e. one recognized by the Me'en as an 'ancestor-clan' (of which there are said to be twelve). This person bears the responsibility for the whole ceremony and by his presence guarantees that it will pass off in the proper manner. The members of these groups coming together for the ceremony are living in the same area, and have their fields for maize or sorghum in each other's vicinity. In the mósit to be described, the four actors came from the Ganguo (Gelit), Degit, Mo'ach and Selakoroy clans. The 


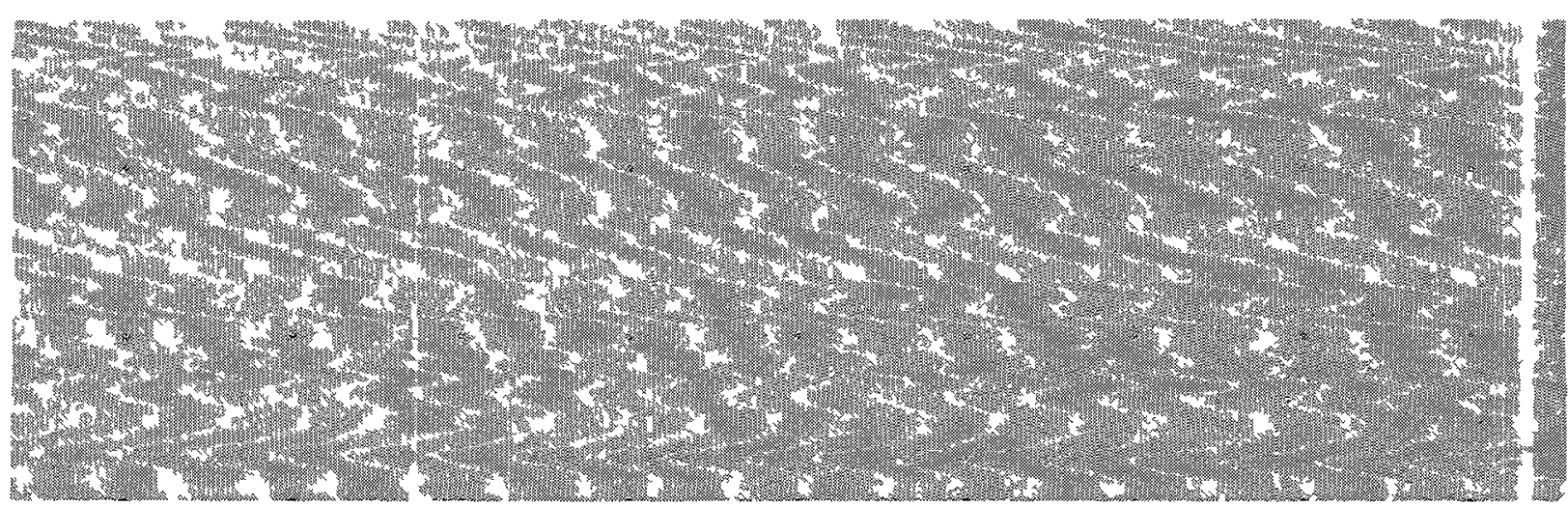

Selakoroy man was the main responsible person. He had to guarantee that the ritual objects were present (some of them to be brought by his kokós), and he also initiated the words spoken during the ceremony.

c) Place and tzme. The mószt is always held in an open space between the fields, 'so that the smoke of the fire can pass over the crops.' Fields not reached are 'smoked' later with fire taken from the main fire made with the tulmit-sticks. The ritual is always held just before the crops are to be harvested, usually one night before the new moon appears in June or July (i.e., approximately the final 'months' of the Me'en yearly cycle). The exact day is often determined by a sign in a dream of a leading member of a Me'en-chim clan. The first ripe ears of sorghum, or cobs of corn, are brought to be used in the ritual. An average móst takes about one-and-a-half hours It should be noted that the ceremony described here was the last and major one in a series of three. In the month preceding the harvest, the most is always done three times for the same group, although in the first two ceremonies, the crop is not symbolically eaten by the participants. only the fire is made and the four main partıcipants are 'painted' with the clay-and-water mixture (see below)

\section{Texts and Acts of the Mósit-Ritual}

The following text from a Me'en mósit-ritual has the character of a long invocation in the subjunctive mood, in the style of a 'prayer' (cf. also Turner 1977) It reflects an underlying concern of this shifting-cultivator people with the need for an understanding or harnony between man and nature. The text is not really a 'Iiturgical order' (in terms of Rappaport's description of this, see Rappaport 1979: 176, 192), and does not have its 'invariance' ( bbld ). The words of a mósit are improvised at every dufferent occasion, although the gist of the 'message' evoked by it is always similar to that of the text presented here. The text, however, is geared to the ritual actions, which form the core of the móstt. What is said, is a commentary on what is done, and in this sense text and acts together are performative

This text was transcribed from a tape made at a mósit for sorghum, in Duma k'ebele (= locality), in the former Goldiya district (now Maji zone) of the Käfa Region. ${ }^{9}$ The Duma area is 


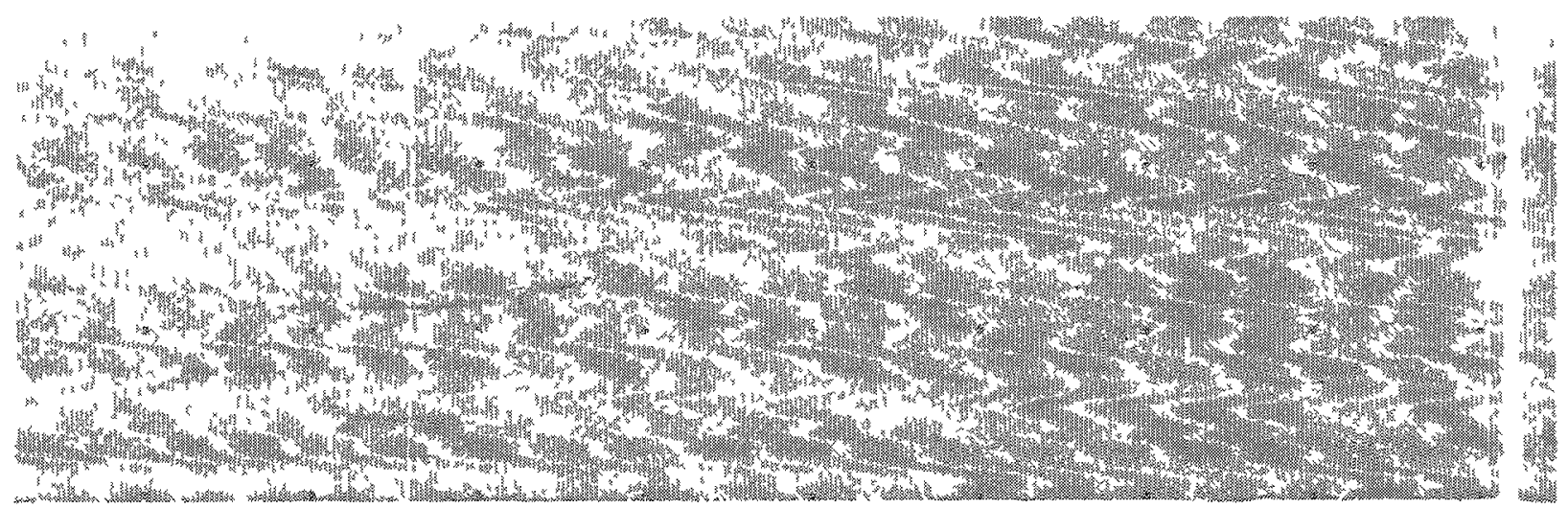

solidly populated by Me'en. ${ }^{10}$ The main speaker is B'olley, the Selakoroy person. His 'respondent' is Mängäsha, his kokó and a member of the Ganguo lineage (part of the Gelit clan). The main action sequences are numbered.

1. The mósit starts when all four 'actors' are seated together on a cow-hide, in front of the ritual objects. The first thing done is the production of fire with the tulmit-sticks. B'olley made the first twisting movement; the three others then followed, each placing their hands on the upper part of the drilling stick, moving and turning it downwards. During this drilling action, the following words were said: ${ }^{11}$

B'olley: Amda kègtu, zuo katala br, zuo katala tongo,

Let the crops ${ }^{12}$ ripen, let people acquire ${ }^{13}$ cattle, let people acquire goats

ngonit kugo, bi kugo, uro kesilu, sholu kivodaju'o,

Let girls come, let cattle come, let the milk be a lot let beer be plenty,

kètè ba-de-gaio, kègit kok-gashak, kanggach kok-gashak.

Let our country be full ${ }^{14}$, let wild animals get lost, ${ }^{15}$ let the baboon get lost.

Zuo katala bi, zuo katala tongo, bi kujugo.

May the people acquire cattle, goats, may the cattle low.

mokach kagama, tongo kugo, zuo katalut, woch kugo kètuana.

Let me marry a woman, let goats come, let people buy it, let girls come to the doors [of the hut].

bi kok-gashak, bi kisllu kadag boyo, br kujugo.

Let the cattle go to the forest, ${ }^{16}$ let cattle grow big and trample the earth, let the cattle low.

amda kègit, sholu kwodaju'o, mokache ngunto koshoro deche,

Let the crops ripen, let beer be plentiful, let the women and girls sit down and urinate, ${ }^{17}$

amda kègit, sholu kwodaju'o.

Let the crops ripen, let beer be plentiful.

amda kègtu, zuo ka-gamda mokach, achuk kugo, bor kugo.

Let the crops be ripe, let people marry wives, let there be meat, let there be honey.

dugutu balıo, bi kugo bak, weyda kègit, bı kızıgna ko-koru.

Let the seeds sprout, let cattle come back here, let the maize ripen, let cattle move to here from the lowland.

ba-de-nanu bro-nuna ande kok-d'okang, a bra tubu-nina ay chang

Let the cattle be blessed and come, what can cause them to disappear? If the cattle are many, where will they go? ${ }^{18}$

Mängäsha: añi kay B'ollena, amda kuda Karaki móstito!

I am B'olley: let (my) crops grow. (Thus) I make the móstt.

B'olley: $\quad$ añ kay B'ollena, amda kègido, mokache de'enua meta ro'osıde
I am B'olley: let the crops ripen, your wife will now give birth 

baboons be hit by the stone,

shua kak-gashak, shotshe kuno.. . [unintelligible word].

let the birds go to the forest, let the bird which comes [....] liba de gekègit haw, liba kègtu.

At this moment they were still struggling with the fire - it always takes some time to produce it. The purpose is not to make it as fast as possible.

B'olley: Kègtt kok-gashak, liba kègtu, amda kudò!

Let the wild animals get lost, let the sorghum ripen, let the crops come forth!

Kèit kabara-kesech whole-chekara. Choba kabar-ne kaasa, choba chekara.

Let the eyes of the wild animals be hurt and lost, let it reach and hurt the eyes of the hog, let the hog be wiped out. ${ }^{19}$

Dukit kogu, dukit kogue kuro kat, koban gashak.

Let disease ${ }^{20}$ go, let it be weakened from the roots, and be thrown out.

Amda kèkgidu, zuo katala br, chaba kok-gashak.

Let the crops be ripe, let people acquire cattle, let the hog go to the forest.

2. Hereafter, the wood-crumbs from the sticks were glowing and were caught on the blade of a knife. Then they were carefully wrapped in the baboon-grass, which was blown into a small fire. With this, the big fire was built, with other grass and dry wood.

3. When the fire was burning, B'olley took the three other plants lying near him (latech, jakach and chubulukuni) and bundled them together with a few ripe ears of sorghum taken from a nearby field. 4. Then, from another ear of sorghum, brought for this purpose also from a nearby field, a worm was taken. Certain worm species are a familiar pest of young and ripening grain. B'olley folded the worm into leaves taken from the three plant species and cursed it with the words

\section{'Dungk'it kokd'ok!'}

(i.e., 'Let the worm be wiped out'), words repeated by the three other elders present. Then they continued as follows. 


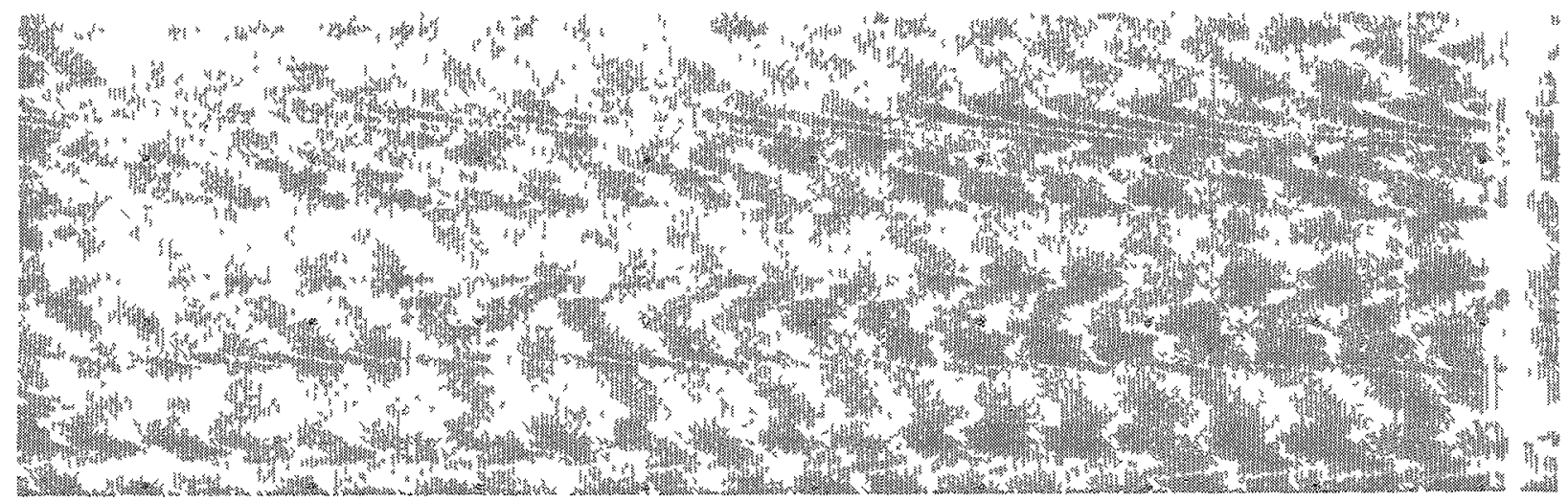

B'olley: Macha, amda kègit ba!

You people, let the crops ripen here!

Mängäsha: Amda kègit! Macha, kuli ${ }^{21}$ shotshe nasu kok-gashak.
Let the crops ripen! You people, [...?] let the harmful birds get lost.

5. At this point, the four actors each took a bite from the bundle of plants and spat it out over the fire.

B'olley:

Amda kègit kororogna mokache kabalshi t'ila,

Let the crops ripen well and let the women prepare food, amo t'ila ki-kienge, libache kikna ki tuma tunto,

let the food be eaten and be in our stomach, let the sorghum grow and reach up to the sky.

kegit geiya ba-dia tegna, kuda meta-ya kanggage tugun gashakò

When we chase the wild animals away from this place, they return soon, those baboons running in the forest.

Antagwui gwuilako. $^{22}$ Liba kuo kangga ber kusoboy,

They bite [...untranslatable]! Let the baboons which enter the sorghum be killed ${ }^{23}$ by the spear,

choba ber kusoboy, neb'ise t'eiti kusoboy, kuda kutu!

let the hog be killed by the spear, let the buffalo be killed

by the bullet, and the skin be brought!

6. In the meantime, a quantity of sorghum stalks was brought by boys and put down near the fire. Also corn-cobs had been brought in a basket, to be blessed by the four elders. Finally, a gourd of b'untila (coffee brewed from coffee-leaves and spices, prepared by women of the nearby homestead) was brought to be used for the blessing.

B'olley: Amda kègtu, amda kègtu, achuk kugo, zuo ga badia,

Let the crops be ripe, let the crops be ripe, let meat come, the people are here.

dungk'itia kokd'ok, zuo kamat-sholuna k'udutna, kidacha.

let the worms get lost, let the people drink beer, be satiated ${ }^{24}$, and live quietly.

Amda kègtu!

Let the crops be ripe!

When this was said, the four elders continued the spray-blessing with coffee and chewed plant-leaves over the fire.

7. When they finished, the women roasted the sorghum in the fire for a few minutes. Then the rest of the people present came forward, many of them with their weapons (spears and some rifles). The weapons were laid in a row near the fire.

8. The four elders then took a mouthful of sorghum and sprayed it out over the weapons in a blessing gesture. 


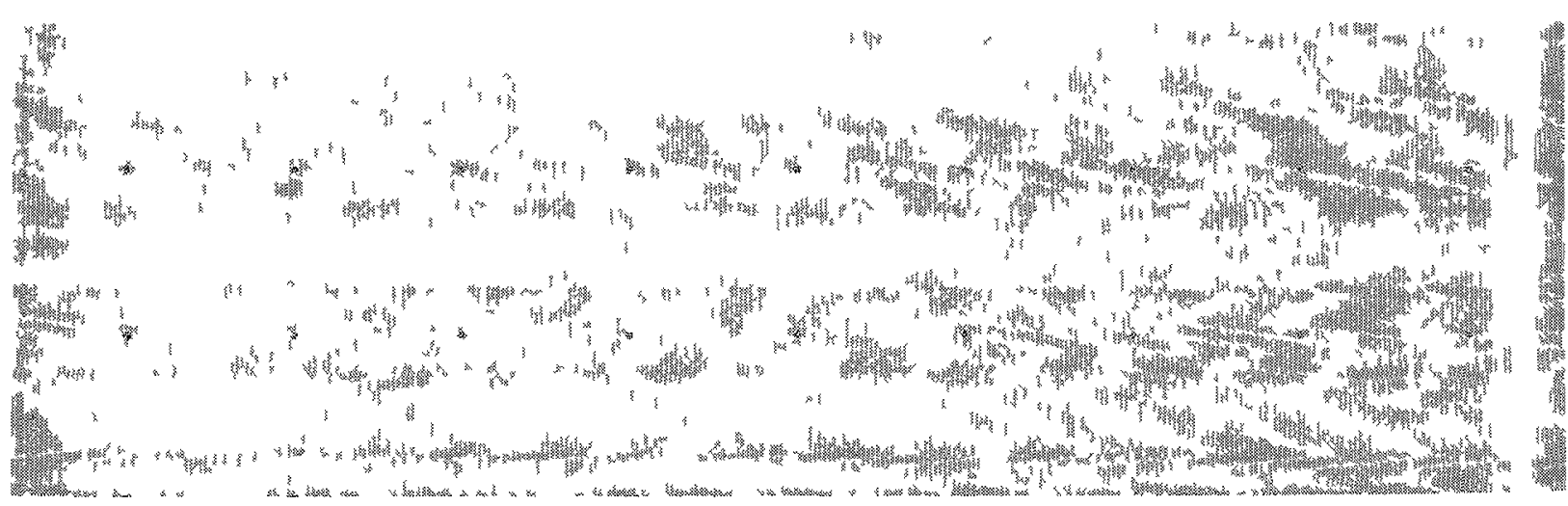

You people, the crops will be very good, and will be eaten (together) with meat of antelope or wild animal, neb ${ }^{3}$ se ga dza twana ber boy this buffalo, let it be pierced by the spear.

Bergu Tuma, koko-de-gato, shi'ech

This year ${ }^{25}$, God, ancestors of ours, hear us

Kanggache zya ber kusu, kogo kusu bèto kuro

The baboons here, let the spear eat them, let them go and eat stone

Then all four people on the cowhide repeated:

Kutuka kus beto kuro, beto kus kabara mad'ak, ber-guo twanaboy Let them all eat stone in their mouth, let them eat stone and hurt their eyes, let them be pierced by the fire-spear ${ }^{26}$

Mangàsha

\section{Añ wochkon bakarañuz}

I have no girl yet.

Ga kunzong?

Aren't you coming?

Gaydutza zenasa woch kona kadagamagyen, amdak, amda èktabuyo For this poor guy, call for him a girl to marry, if the crops ripen, let her go and work

9. At this point, the red earth was crushed with the black stone and then mixed with water and some ash of the baboon-grass. The four people on the cow-hide then proceeded to 'paint', with crossed arms, each other's forehead, cheeks, chest and arms with this mixture B'olley used the black river stone to apply it on the stomach of his partners. They then said to each other:

B'olley'

Komach kiked'alina kit'ın.

Let our strength increase and be spared

Mangasha Kotoy bana krrm amda

Let him go and eat grain

Kukz keyamo

Let disease be cast back

Kubula chekara

Let it be taken off [to a bad place ${ }^{27}$ ]

Kokchamo chekara

Let it go [to a bad place]

Then all four people together: 
10. Subsequently, the rest of the people came forward to be smeared with the water-clay mixture. In the meantime, women roasted the rest of the sorghum in the fire. B'olley poured out some of the coffee from the gourd on the ground, near the fire. He then smeared some of the sorghum ears with the clay mixture, and put

11 The rest of the sorghum was taken by the four elders and 'poured' into their hands by turn, whereby a Me'en-chím man gave it to his kokó and then received it back. They threw some of it backwards over their shoulder, and some in front of them. Only then they could actually eat the sorghum, but again part of it was spat into the fire. When the rest of the participants came forward, they received roasted sorghum from the four elders, through B'olley, who gave it to his kokó (Mängäsha), who gave it to the people.

12. While all held the sorghum in their hands, the four elders went to sit in front of the fire in a row, B'olley in the front. Then the final words of the ceremony were said by him:

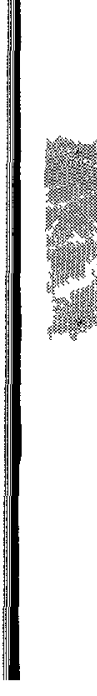

$$
\text { | }
$$
B'olley Kokoı diañ, Boroba, Bulch'a, mokach zuo sèke Shu'aya, My forefathers, Boroba, Bulch'a, the woman people called Shu'áya amda kègtu múk' Let all the crops be ripe, all' goñzt, goñt, gaas ${ }^{t w} a$ kugo Bow, bow, ${ }^{28}$ she will come near Ande kun amda tèko ber-guo koktek' Let the fire-spear kull all that which comes to the crops'

13. All people then ate the sorghum. The remaining coffee was drunk by the four elders and sprayed out over the weapons. With the last bit, B'olley poured out the final libation on the ground, presumably for the ancestors he just mentioned (and by implication for those of the other three clan representatives).

14. The owners of the weapons came forward to take them back and then ran out in all directions shouting ' $W u$, wu, wu', symbolically chasing away all the pests and wild animals referred to in the previous text.

The final stage of the mósit was, as usual, the singing and dancing of seasonal songs called gule, well into the night. This is not part of the ritual proper.

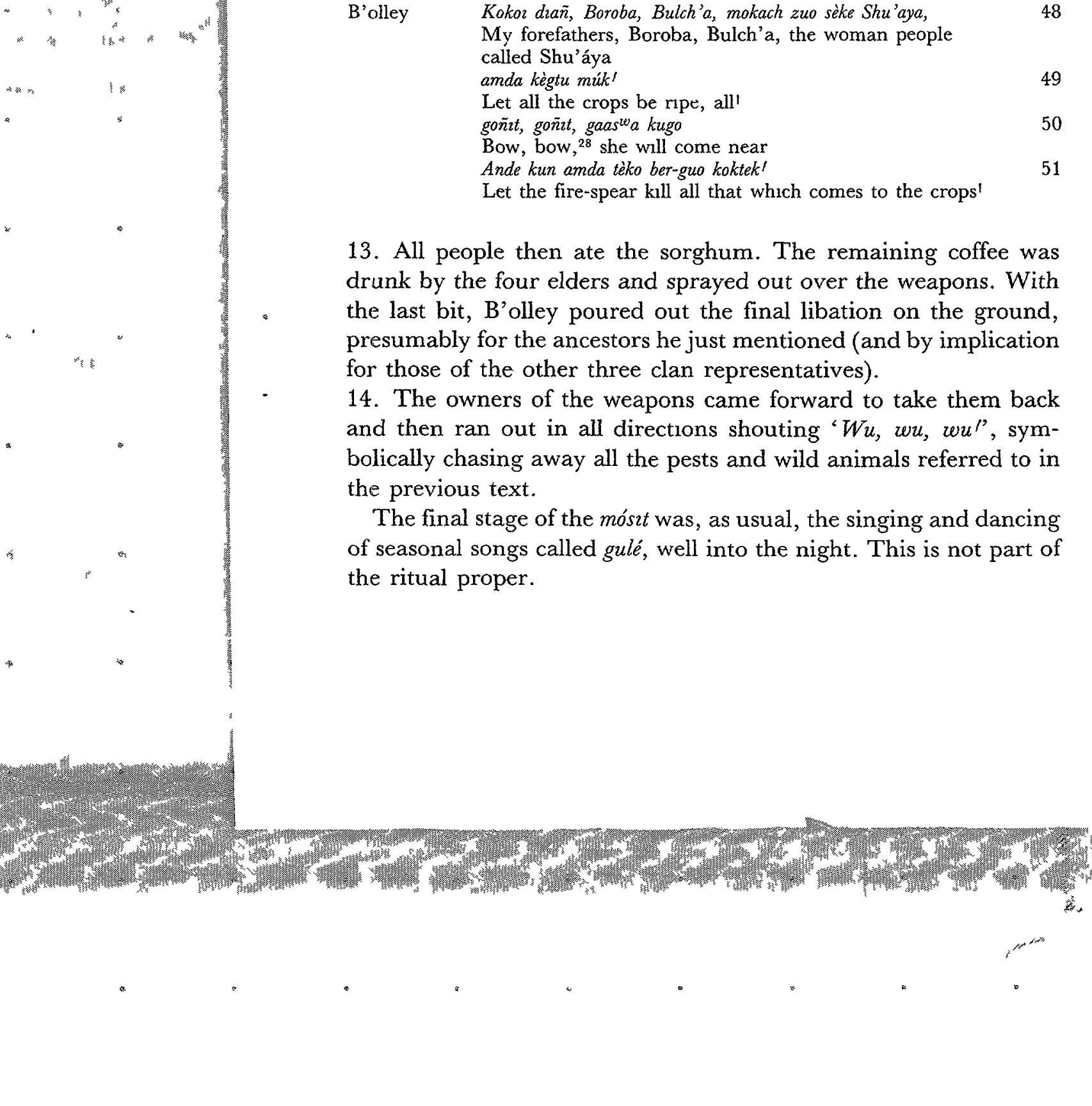

(n)




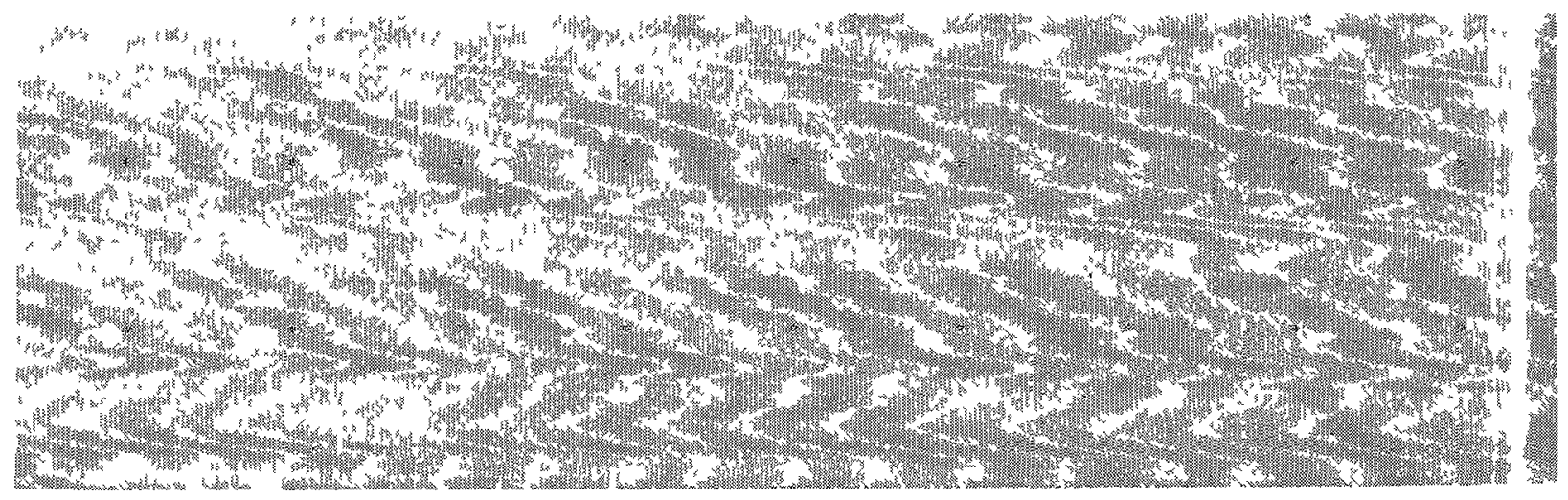

\section{An Explanatory Description of the Ritual Sequence}

The ritual was described above in 51 lines of text accompanying 15 action sequences. These can be reduced to 5 action components (or 'action elements' in Lawson \& McCauley's terminology, 1990:87), which express the organizing ideas of the ritual. They are the following:

a. the creation of fire (numbers 1 and 2)

b. the cursing of potential crop destroyers (3-4)

c. the blessing for protection of the crops (5-8)

d. the protection and strengthening of the people (9-10)

e. the appeal to the superhuman agents for confirmation of the preceding and giving evidence of being strengthened (By taking up the arms and lashing out at the competing animals) (11-14).

Within the constraints of the aims of these action components, the participants know what to do and what not: they follow the 'script' or recognizable pattern (Lawson \& McCauley (1990:84f.), one can translate the five points above into a formal description of the structure of action, or a cognitive representation of the ritual which reflects, ultimately, the particular commitment of the religion's conceptual system. (ibid.: 87). Within the limited scope of this article, the accompanying 'tree structure' figuresanalogous to the structural trees of generative linguists; see Lawson \& McCauley 1990, Ch. 5-will not be given here. The important point is that the final action element (11-14) presupposes the previous four ones and is, in terms of the ritual structure of the mósit as a whole, the culmination of it. A brief commentary on the acts of the ritual will illustrate this irreversible order.

* For the ritual to have force, fire has to be created 'from nothing', as if it did not exist. It would, for instance, be completely beside the point to take it from the hearth of a nearby homestead. Fire was given by Tuma to humans. The smoke of the fire 'cleans' or 'protects' the crops on the fields. In the mósit, it also figures as preparation for the use of the ripe crops as food for the four groups which have grown them.

* The fire burning, and the three ritual plants prepared, the animal crop pests (in the form of the worm) can be ritually attacked, 'sent back to the forest', or destroyed.

* The ripe sorghum of this year's harvest cannot just be eaten as one likes: it must be blessed and dedicated to the power(s) which 


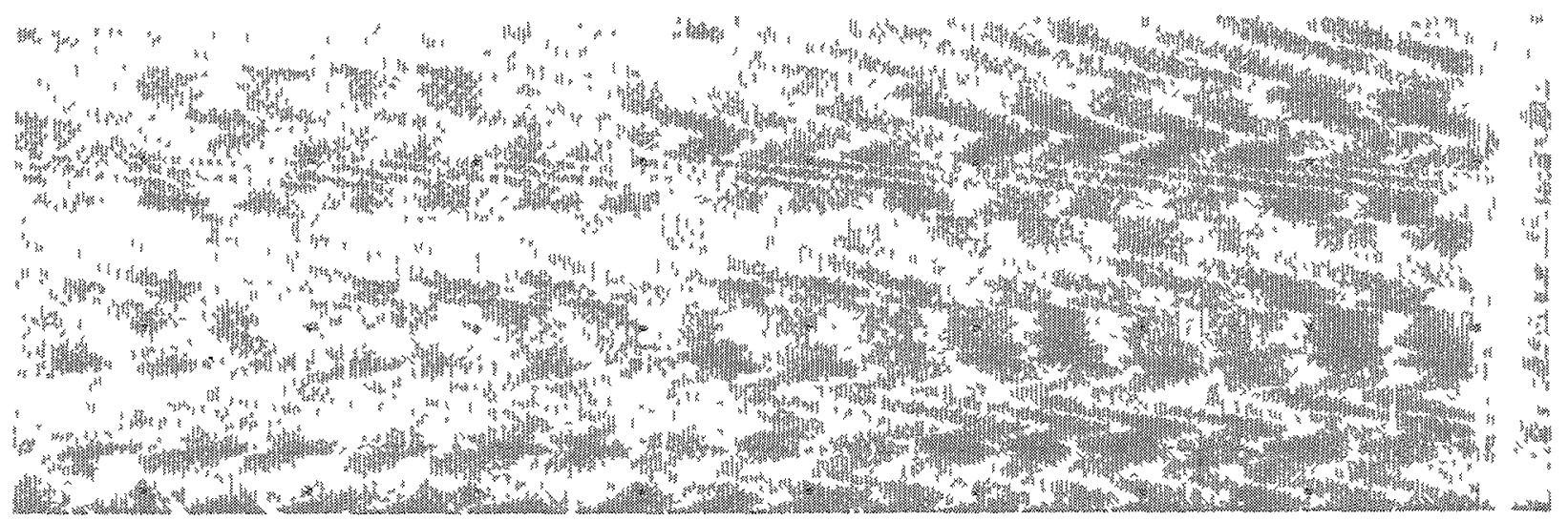

made it grow, in a general sense. Also the human effort needed for defending the crops (against the various animals) is to be acknowledged. This is done with the spray blessing (an obvious analogy with rain from Tuma) with the mixture of the chewed plant leaves and coffee (always used in a ritual context).

* The next episode continues with the 'strengthening' of the participants (responsible for the past and coming year's actual work) with the mixture of water, ashes from the grass and the red soil. The round black basalt stone used for applying it comes from the Omo river, which the twelve original $\mathrm{Me}^{2}$ en clans see as their place of origin. Note that this ritual strengthening of the people comes at the end of the growing season when stocks are low, before they partake of the plentiful new harvest (and of the fresh sholu beer made from it) which will in fact give them new strength.

* At this point, the new sorghum can be eaten by the four participants together, seated in the peculiar row, making the call to the ancestors. We see here that the final spray-blessing and libation of coffee and the words said here (lines 48-50) are the most important ones, containing the final call to superhuman agents to ally themselves with the living for protection and strength. (Shu'áya was a female in the patri-clan of B'olley, the main agent in the ritual). After the appeal to Tuma, the one to the $k$ 'alua, the spirit of the ancestors addressed through Shu'áya, closes the ceremony, and underlines the commitment in this ritual to the agency of these few superhuman agents, within the religious conceptual system of the Me'en. This final 'statement' in the ritual makes use of all the preceding embedded ritual actions (making the fire, cleaning the crops, protectively 'painting' the people, 'sending off' animal competitors into the forest, roasting the new sorghum, beckoning Tuma and the ancestors) for the concluding commensal act of the four clan representatives and the confirming of their continued cooperation.

In the ritual we see that the role of two principles held to be universal in religious ritual systems: the principle of superhuman agency (Lawson \& McCauley 1990; 124) and the principle of superhuman immediacy (ibid.: 125). They state, respectively, that postulated superhuman agencies are in some way held to be acting in the context of the ritual, and that they are seen as immediately involved in the ritual. Both principles are at work in the mósit (see again, lines 36, 48 and 50). Here, Tuma and the ancestors are 


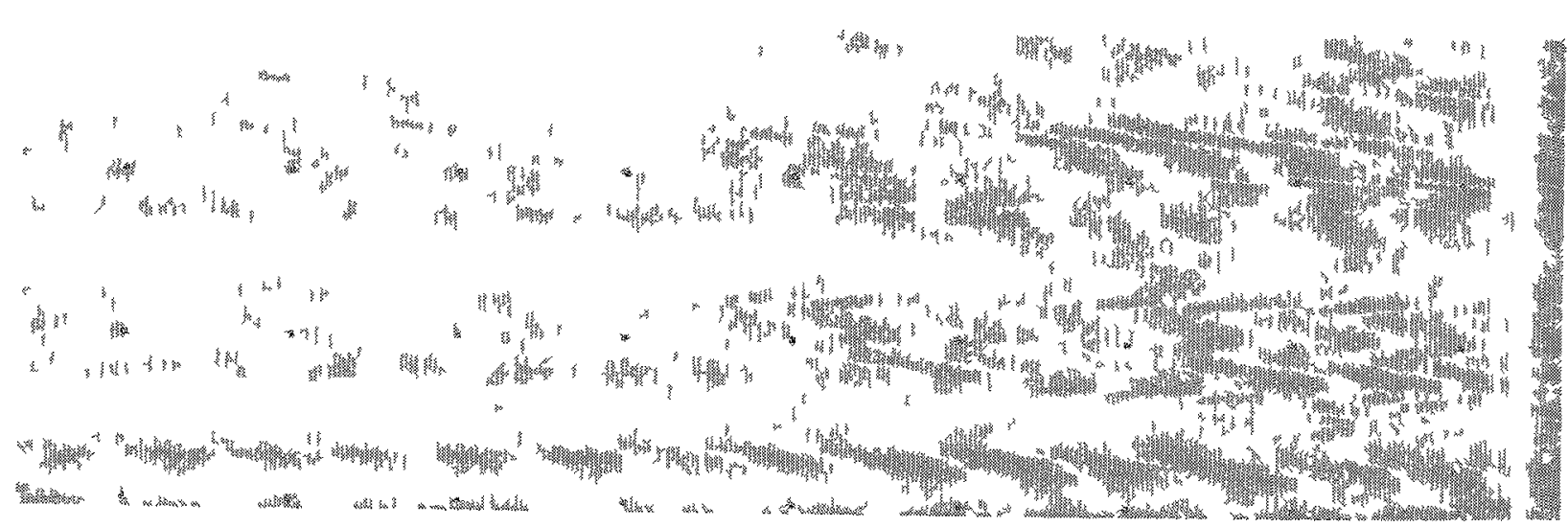

asked to listen to (and grant the people) what they plead and hope for, and in the second instance an ancestor (Shu'áya) is seen as 'coming near'.

The implied role of the superhuman agents in the mószt is, however, limited The ritual demands as much the active participation of humans themselves and their engagement with their environment The understanding or the 'contract' with nature, and also with the 'social partners', representatives of which were seated on the cattle-hide with B'olley, has to be renewed According to the prediction of Lawson \& McCauley (1990: 134-135), the móst is by nature an annual ritual with limited effects, which must be repeated.

\section{Interpretation}

We have seen that for an explanation of the mósit cultural information on such things as the composition of the four officiating people, the purposely difficult way of making fire, the particular plants used, the protective substance smeared on people, etc are all interwoven in a complex but structured pattern with which the participants are famuliar, i e , on which they have competence

In this section, further interpretive notes on the background and setting of the ritual in Me'en culture are given, in order to complete the general account of the previous section As Lawson \& McCauley repeatedly stated, in addition to the description of the action structure of the ritual, the interpretive context has to be clarified to provide a fuller understanding of its semantics

\section{Environment}

As may be apparent, there are very direct environmental or ecological referents in the text The words reflect the central concerns of the people involved growth and abundance of staple crops, protection against disease and pests, enhancing the reproductive capacity of domestic animals and people (as evident from the frequent references to women and marrying) It appeals to an idea of cooperation or symbiosis of man and nature in general. Each is urged to stay in its proper place: wild animals, worms, birds, etc., should stay in their domain - the forest-and humans and domestic animals should receive their share of produce according to what they have 'invested' 


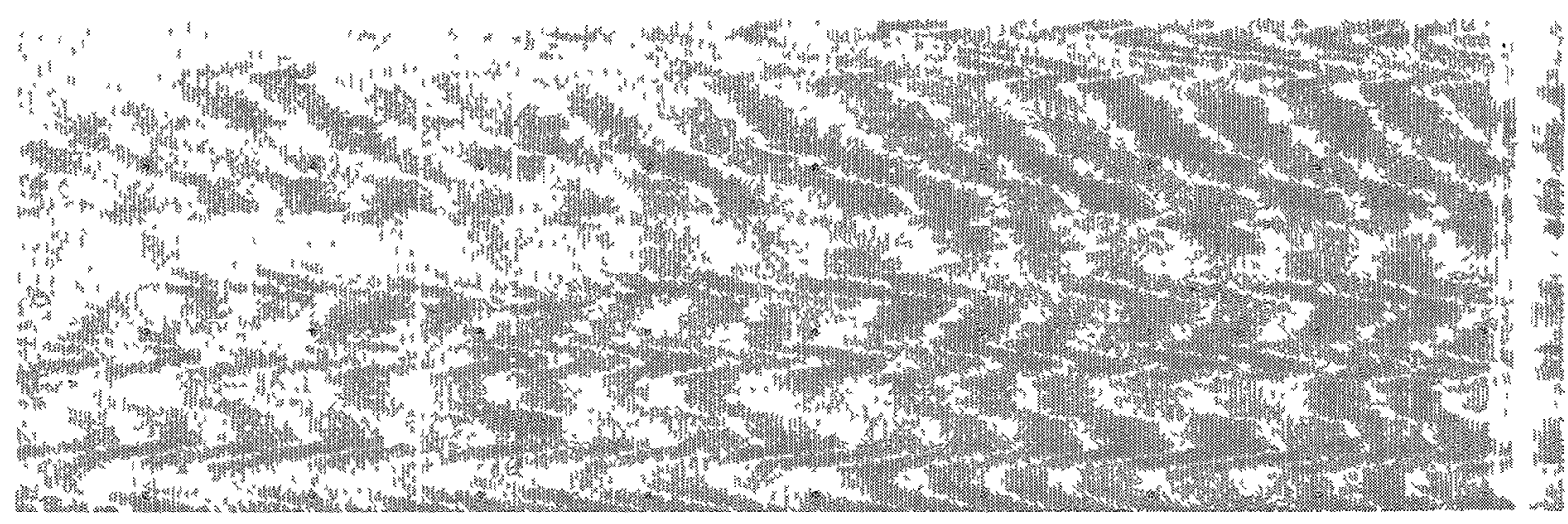

A direct reference to rainfall, the central prerequisite for good crop yields, is absent (the one reference to Tuma-the word meaning 'God' as well as 'rain' and 'sky'-clearly is to God). The mósit seems to deal almost exclusively with animate beings which can threaten the crops when they are near harvesting. There are a few crucial references to the superhuman beings or agents, but otherwise the supernatural aspect does not dominate. The natural world, the world of the ancestors and the world of the living are seen as part of one whole. This ritual is both an explicit, protective performance aimed at competitors of the human population, as well as a general appeal or prayer to a transcendent or superhuman power which controls the more basic conditions of growing power, temperature and rainfall (Tuma), and fertility of the soil of the forefathers and-mothers and of the descendants (ancestors). The ritual contains an appeal and a threat (by means of the expressed intention to use the spears) and thus 'communicates', to the natural competitors to remain in their own domain, away from humans. The various plants used in the ritual (apart from the tulmit) are strong lowland plants, relatively pest-resistant. They are traditionally seen as 'hot', powerful plants, and thus perhaps provide either a kind of 'model' for the ripening crops, or an alternative wild food source which the forest animals should eat instead of the planted crops. Nevertheless, the precise reason for these plants (see above, The Setting) having been selected can perhaps never be revealed.

\section{Social Structure}

As we saw, the mósit carries an element of 'auto-communication': from the setting and the composition of the group of 'actors' it is clear that a 'message' is expressed by, as well as sent to, the participants, and it is here that an additional aspect of morality is constituted. The ritual appears to express a careful balance between representatives of specified local groups which are basically 'equal' in status terms of resource use, labour effort and domestic organisation and are partly dependent on each other as well. There is also a playful reference to the possible affinal bonds between the groups (lines 39-41). Apart from the mósit, this idea of balance is also expressed in the Me'en rituals of marriage, burial and disease control. Although in the mósit performance, a member from a Me'enchim clan is the most important officiating person (by virtue of his 


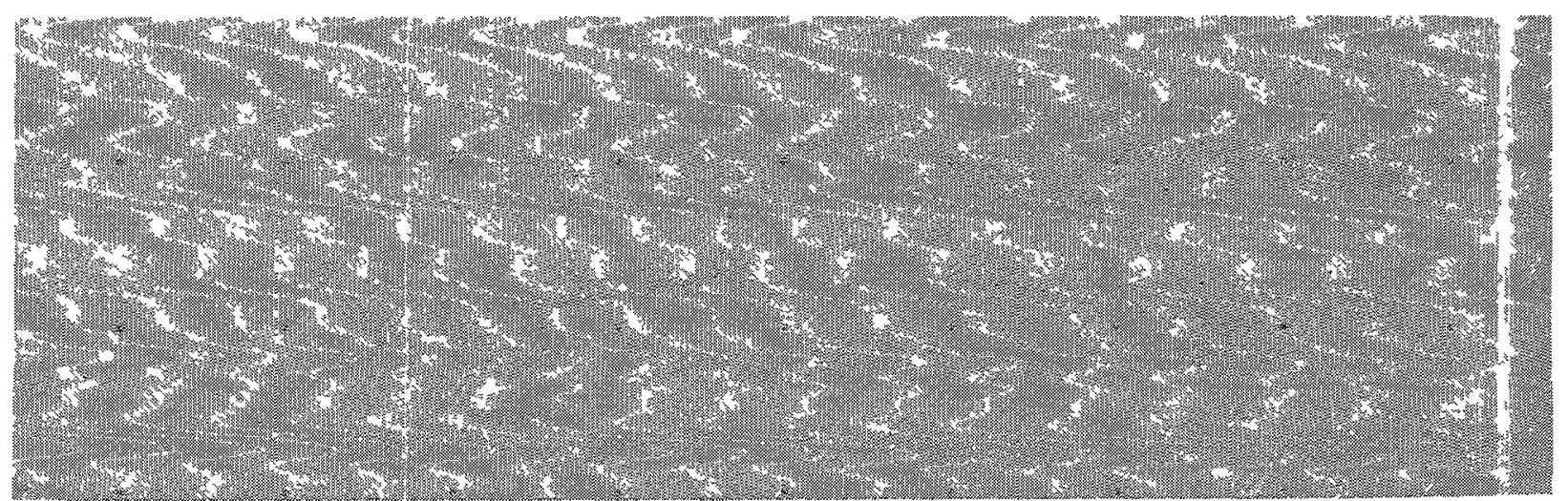

inherited membership of a 'founder clan'), the others are not really lower in status: there is only a 'division of labour' in the ritual performance. For all practical purposes, the (members of the) groups are equal: differences in power and social distance are not relevant in the ritual. They are neither pervasive in real life.

It is an old question of why people engage in ritual, and of what the status is of the kind of 'instrumental connection' they see between what they are doing and the 'effects' they may hope it will produce. While great care was taken to carry out the correct order and manner of the ritual actions, the measure of playfulness and joking which was observed during this mósit was notable: a sense of humour is not forbidden. This and the general subjunctive style of much of the text itself suggests that any simple causal connection is not asserted by the Me'en participants. They know that ultimate determining factors are things like sufficient rainfall, selection and care for crops, their own hard work in the fields, and their being alert to animal pests throughout the growing period (e.g., by guarding and armed repulsion of pigs, buffaloes, and baboons). But the ritual as an activity indeed brings together people to produce a 'model', or to uphold and assert a norm of group cooperation and of harmony of humans and the wider environment. Granted the general but remote assumptions of their religious world-view, it may not be more than that: basically the expression, along analogical lines of thought, of an ideal, the realization of which is always precarious. The ritual activity also canalizes the felt need for cooperative group-labour in an indirect way, thus-as politeness theories of social life have it (cf. Strecker 1988: 204)-reducing the recourse to major 'face-threatening acts' between individuals and groups living on terms of relative equality, placed in a shared, jointly apprehended and appropriated environment.

One might say that the ritual model as such 'works' in Me'en culture. The fact that, in the common view of scientifically-minded and other outsiders, most of the postulated connections may be wishful thinking or just wrong is irrelevant. This is a neointellectualist interpretation which does not exhaust the range of meaning of ritual (which, as we saw above, does not by definition have a referential dimension). Newton's physics was also proved 'wrong' by subsequent theories like relativity theory and quantum physics, but this did not prevent it from working for a long time and giving rise to numerous research questions, inventions and applica- 


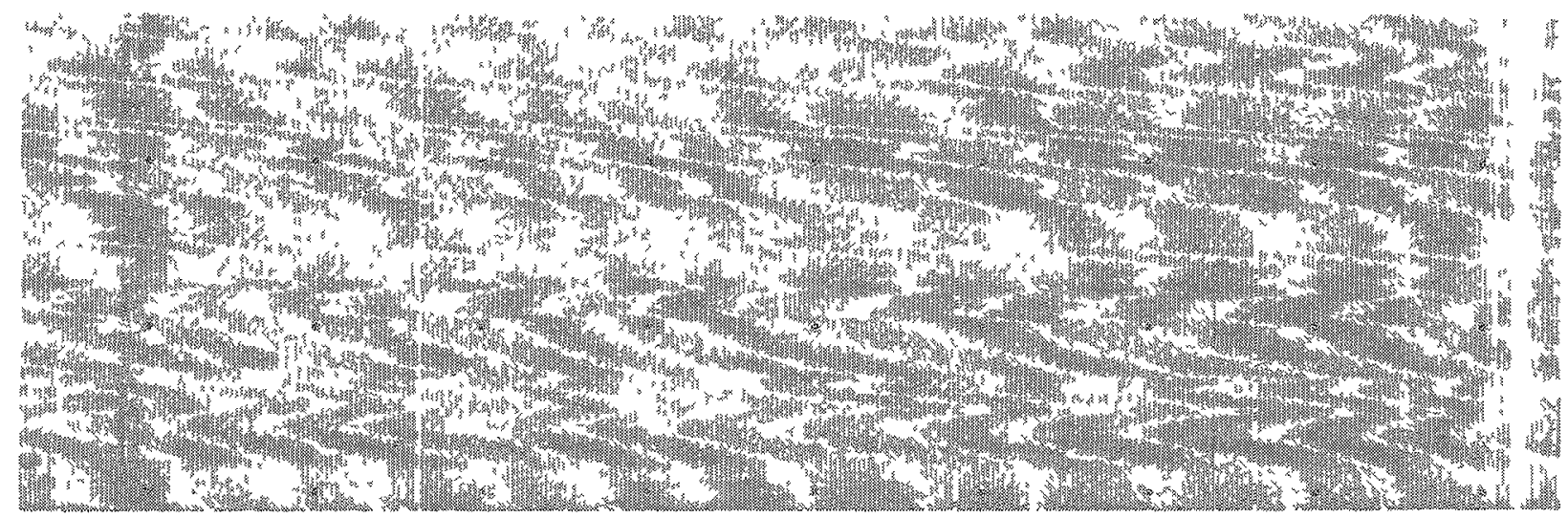

tions (Cf. the points made earlier about the theory of 'affordances' of the environment, to which humans directly and pragmatically respond).

\section{Cognition and Control-The mósit as 'Religion'}

The Me'en obviously do not adhere to Christianity or Islam, and indeed have no interest in these faiths. Looking at this central ritual, the mósit, it cannot be said that they 'have no religion' (A statement one often finds in reports which used to be made by the southwestern district administrators gathering basic ethnographic information on the ethno-cultural groups under their control). If 'religion' is meant to refer not only to the 'high' or 'revealed' religions but to all systems of belief in cosmological connections between humans and nature and to moral rules following from them, then a ritual like the mósit has a clear religious dimension. In the section on Delineating ritual above, we mentioned Rappaport's view on ritual as having a dimension of morality. This we recognized on several levels: 1 . the belief in the mutual influencing of humans and nature, as directly evident from the text, 2 . the connection with the superhuman agents important in the Me'en worldview, and 3 . the social setting of the ritual's performance. First, in the text itself, we saw that an attempt is made by the concerned people to 'appeal' to Tuma (God), albeit only once, to the ancestors of their clan-or family-groups, and to nature to let their means of livelihood grow undisturbed. It is thus an effort to establish a moral understanding with the natural forces which partly threaten them, as well as with the supporting force of the superhuman agents. Secondly, a look at the setting of the mósit showed that the idea of cooperation or of 'contract' between human groups of diverse origin is present: as we saw, it is always performed by members of local groups who are dependent upon each other in a real sense. Also, if the crops in one year fail, the next year's mósit is performed by a different combination of people, from different clan-groups.

Via Lawson \& McCauley's theory we saw that there is a clear connection of the ritual with the wider religious conceptual system of the Me'en as a whole. Without referring to this connection, the ritual could not really be explained. The mósit thus seems to be covered by the description of ritual given above in terms of cognition. First of all, the body of ritual actions is traceable and explainable in terms of general psychological mechanisms and 


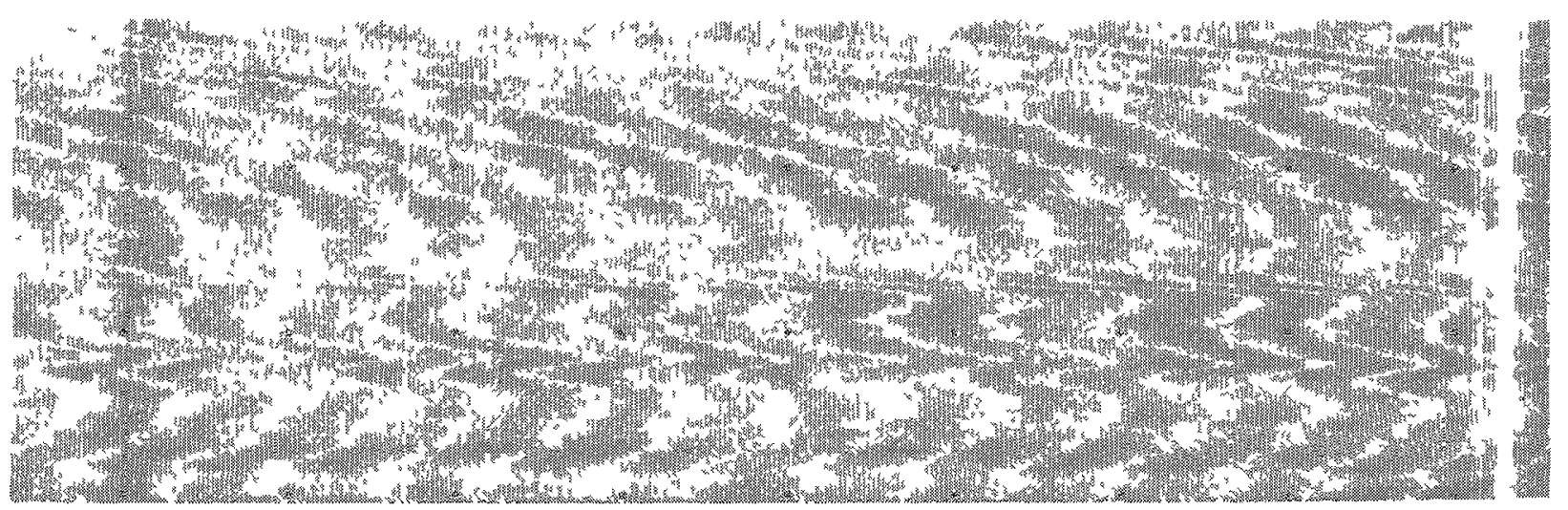

reveals generative patterns. Secondly and connected with this, there is the underlying concern, seen in much of the text, with a desire for control, for making non-human forces manageable. The ritual is an enacted drama drawing near the natural and the human for the purpose of establishing an order or a contract between human activity and nature's activity which may be in competition with each other. This is also suggested by the subjunctive style of the text throughout: to whom are those invocations (in the basic schema of 'Let the good come to us and let the bad stay away or be chased away and killed') addressed? The answer came towards the end of the text: not only to Tuma, but especially to their ancestors (especially Shu'áya), who have inhabited the land before them and may still influence the lot of their descendants. In other mósit texts which I heard, references to local spirits ( $k$ 'olle) were also made. These various concepts are ideational representations, which have a partly explanatory and partly self-referential function in the world-view of the Me'en, allow them-in the ritual with its formal sequence of acts and stages-to construct meaning via social drama. The representations form the religious conceptual system within which the ritual acts move to establish meaning and order in the relations of the Me'en with their environment, which they know intimately but which always remains insecure.

\section{Conclusion}

The above analysis and explanation of the mósit ritual of the Me'en has not been limited to a thick description but has purposely been placed within a wider theoretical frame inspired by a cognitive approach. No large claims have been made here toward any ultimate explanation of the mósit ritual or the larger religious conceptual system of the $\mathrm{Me}^{\prime} \mathrm{en}$, but its basic action structure and organisation have been explicated, and its meaning in the wider religious conceptual system and way of life of the Me'en has been clarified. Besides the more religious rituals, the Me'en know also 'secular' rituals (where the role of superhuman agents is not referred to), like the purification ceremonies after homicide or adultery. A weak point in Lawson \& McCauley's cognitive theory may be that it does not address such rituals. Here Rappaport's view on ritual as an organized human effort to establish a 'morality', a 


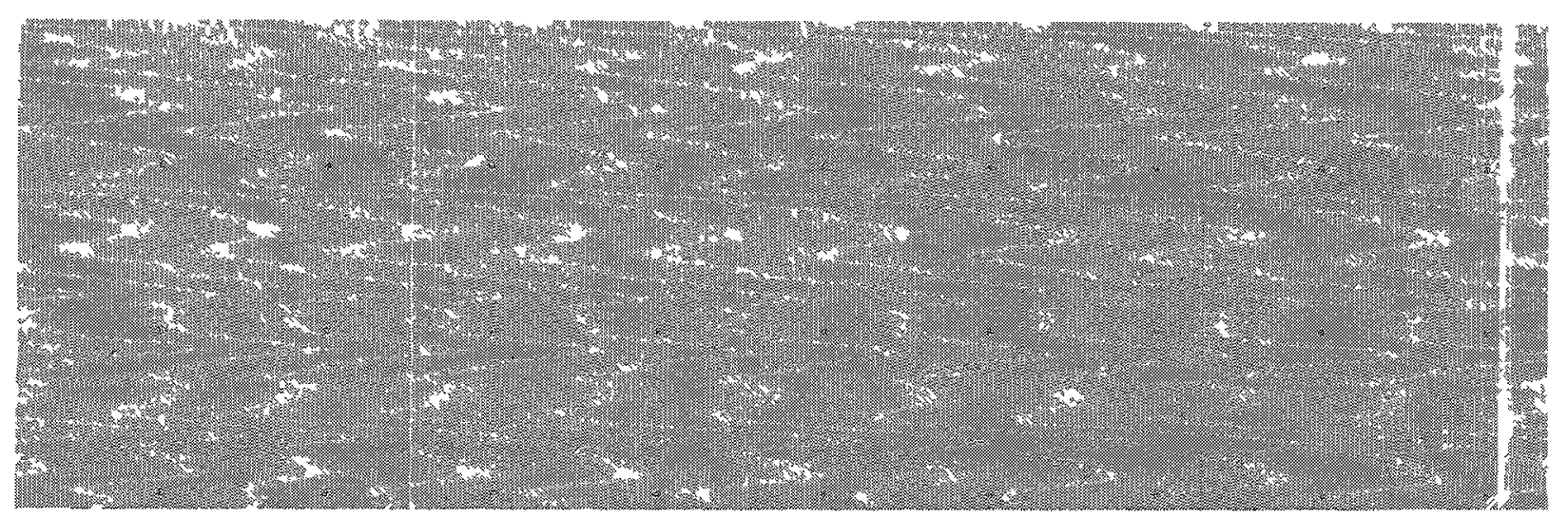

social contract, may be fruitful, because it may allow us to locate the cognitive endeavour of humans in their very socialzty.

The mósit ritual discussed here is of course not unique in its kind. The many commonalities in annual or seasonal rituals as they are known from the ethnographic record, cross-culturally and over large time-spans, do lend themselves for systematic comparison. Ultimately, the inner logic which religious ritual obeys is, plausibly, a reflection of the organisational constraints of the cognitive human mechanism on cultural material. In this light, the theory offered by Lawson and McCauley, by starting to look at the action structure of ritual, can be productively used as a springboard for comparative explanations of religious ritual systems.

\section{Acknowledgements}

A rather different version of this article was presented as a paper at the Second National Conference of Ethiopian Studies, held at Addis Ababa University in October 1992. For providing research grants for fieldwork in $1989-90$ and $1990-92$, I am very grateful to the Wenner-Gren Foundation for Anthropological Research (New York), and to the Royal Netherlands Academy of Sciences (KNAW). I thank the Institute of Ethiopian Studies at Addis Ababa University and its then director, Dr Taddese Beyene, for crucial support. Finally, I express my continuing debt to the Me'en people for their generosity and interest, especially to the late Mangasha Kabtimer and to the indomitable B'asagala Galtach, elder of the Selakoroy.

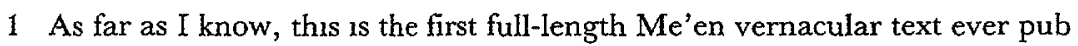
lished For two other brief texts, see Abbink 1992

2 Ingold's analysis (based on the work of psychologist J J Gibson) does not preclude this view (cf Ingold 1993 54) The author only does not elaborate upon it

3 See Abbunk 1988

4 Cf Lawson 1993 206, note 5 the conceptual system of a culture is not always thoroughly integrated The agro-pastoral 'Bodi'-Me'en (who call themselves Mela and Chirim), a group of ca 4000 people living in the lowlands east across the Omo River, do not have spirit mediums like the Tishana. Unlike the Tishana, the Bodi have not adapted their way of life to that of neighbouring highland cultivators 


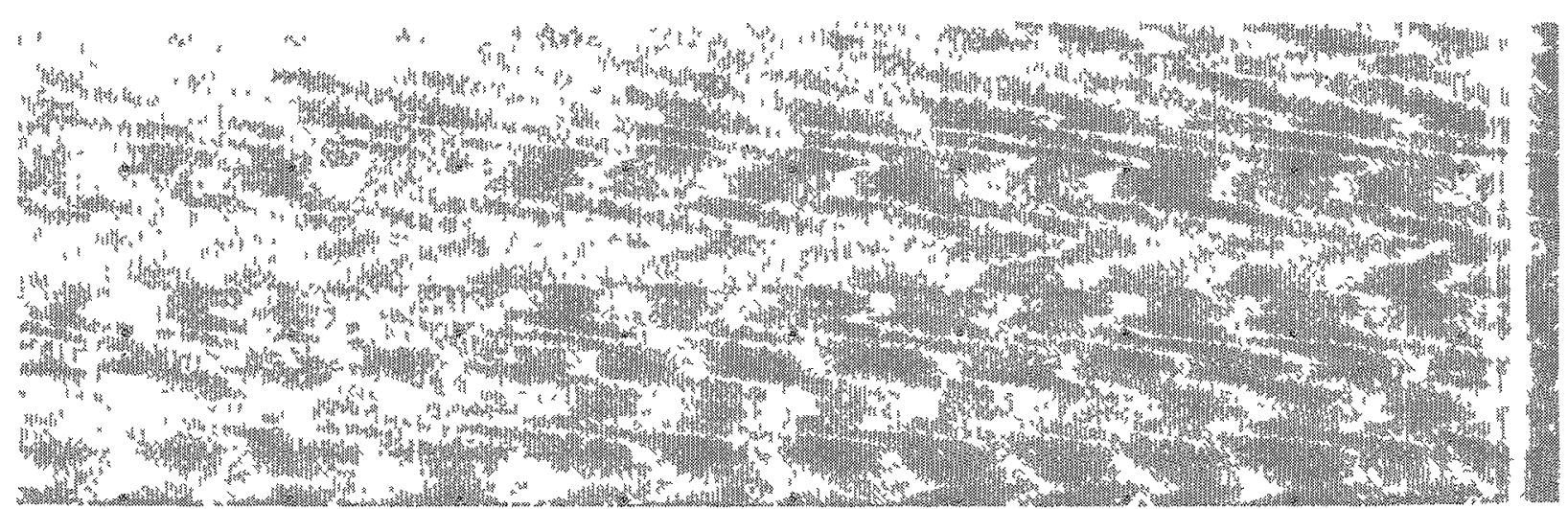

5. To complete the picture of the religious situation, it must be added that since 1991 there is an evangelical mission station at the northern fringe of the Me'en area, staffed by foreign and Ethiopian missionaries, nurses, and language educators of the (Ethiopian evangelical) Kalehiywot Church and the SIM (Society for International Missions). While the Me'en are happy with the clinic and the educational program due to start in their own language, they do not show much interest in the new belief. The missionaries do not accept Me'en culture as it is now, rejecting, for instance, the drinking of the alcoholic sholu beer, the custom of killing of cattle (a productive resource) at funeral ceremonies, and the consultations of the diviner-magicians.

6. Goldschmidt (1986: 114-115) mentions a similar ritual called korosek for the Sebei people in Uganda. Here also, fire-sticks are used, and special plants with 'cleansing properties', and later specimens of food-crops, are placed on the fire. Goldschmidt calls this ritual a 'harvest' ritual, to protect the crops from disease. As mentioned above, the Ethiopian Suri people, living southwest of the Me'en, have a similar ritual, called moshui. Nevertheless, the Me'en ritual as described here is a more elaborate version.

7. The word 'clan' is used here in the sense of a named, exogamous, group. Individual membership is not strictly determined by descent criteria (see Abbink 1992).

8. The two tulmit-sticks are sometimes also called 'female and male' (mokacho-machi).

9. I express my thanks to Ato Bizunäh Misikkir of Bach'uma village, Käfa, for checking the translation, and for other assistance during fieldwork. I am also deeply grateful to Ato Mäkonnen Yayye for his valuable comments.

10. The ritual was observed on September 25, 1989.

11. Usually there was a shorter or longer pause between the sentences. They were not said in haste.

12. Amda usuallyu refers to grain-crops, like sorghum, maize or t'eff; not to root-crops, pulses or cabbage.

13. Litt.: 'buy'.

14. In the sense of 'abundant', 'well-stocked'.

15. Litt.: 'go to the forest'.

16. I.e., to graze.

17. I.e., anywhere outside the compounds, without danger.

18. Translation uncertain.

19. Translation of 'chekara' uncertain. It means something like 'go to a bad place', or 'get lost'.

20. A kind of epidemic.

21. Meaning of 'kull' unclear.

22. Archaic expression.

23. Litt.: 'be eaten'.

24. Litt : 'be drunk'.

25. Bergu means actually the yearly 'growing season'. An alternative translation might be: 'season of God', or: 'growing season which you God have in your power'.

26. I.e., a very tough, well-made spear.

27 Translation uncertain.

28. In the sense of 'paying respect'. 


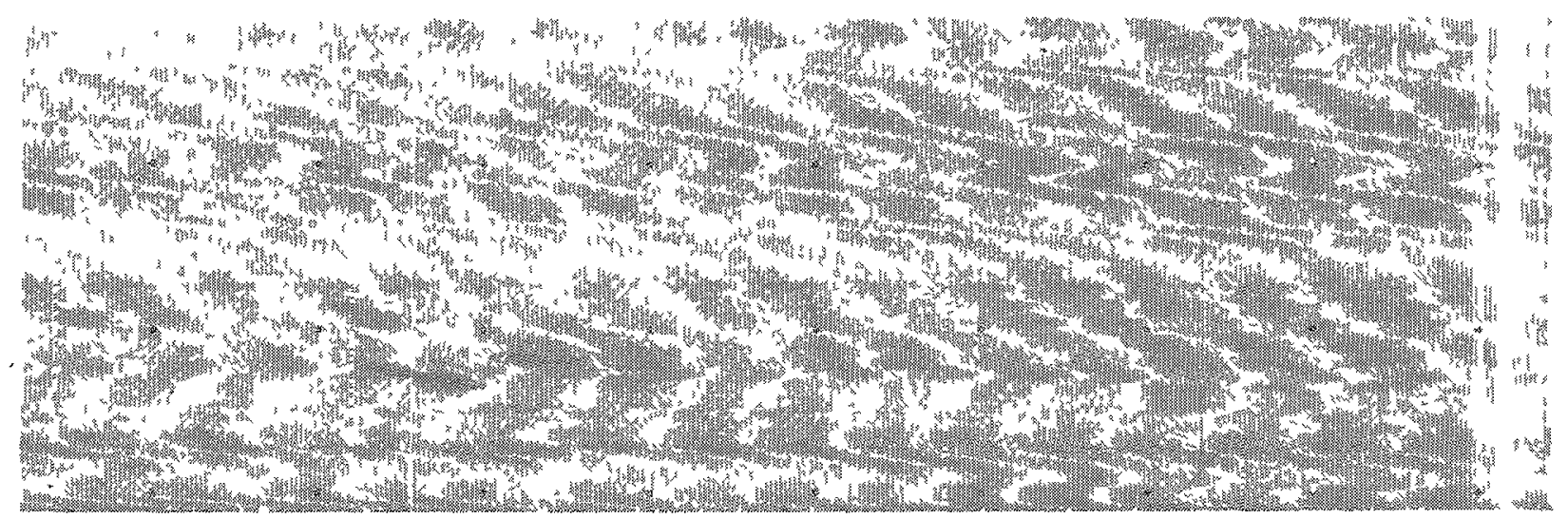

Ritual and Environment

\section{REFERENCES}

Abbink, J.

1988 Me'en means of subsistence: notes on crops, tools and ethnic change. Anthropos 83: 187-192.

1990 Tribal formation on the Ethiopian fringe: toward a history of the 'Tishana'. Northeast African Studies 12(1): 21-42.

1992 An ethno-historical perspective on Me'en territorial organization (Southwest Ethiopia). Anthropos 86 (4-6): 351-364.

1993 Reading the entrails: analysis of an African divination discourse. Man (N.S.) 28(4): 705-726.

Barth, F.

1975 Ritual and Knowledge among the Baktaman of New Guinea. New Haven: Yale University Press.

Doty, W.G.

1992 Wild transgression and tame celebrations. Journal of Ritual Studzes 6(2): 115-130.

Goldschmidt, W.

1986 The Sebei: a Study in Adaptatzon. New York: Holt, Rinehart and Winston.

Guthrie, S.

1980 A cognitive theory of religion. Current Anthropology 21(2): 181-203.

1993 Faces in the Clouds. A New Theory of Religion. New York: Oxford University Press.

Ingold, $\mathrm{T}$.

1993 Cullure and the perception of the environment. In: E. Croll \& D.

Parkin, eds. Bush Base: Forest Farm, pp. 39-55. London-New York: Routledge.

Lawson, E.T.

1993 Cognitive categories, cultural forms and ritual structures. In: P. Boyer, ed., Cognitive Aspects of Religrous Symbolism, pp. 188-206. Cambridge: Cambridge University Press.

Lawson, E.T. \&x R. N. McGauley

1990 Rethrnkıng Religion. Connecting Cognztzon and Culture. Cambridge: Cambridge University Press.

Lewis, G.

1980 Days of Shıning Red. An Essay on Understandıng Rutual. Cambridge: Cambridge University Press.

Keesing, R.W

1991 Experiments in thinking about ritual. Canberra Anthropology 14(2): 60-74.

Rappaport, R.A.

1979a The obvious aspects of ritual. In: R.A. Rappaport, Ecology, Meaning and Religion, pp. 173-221. Berkeley: North Atlantic Books.

$1979 \mathrm{~b}$ Ritual regulation of environment relations among a New Guinea people. In: R.A. Rappaport, Ecology, Meaning and Religion, pp. 27-42. Berkeley: North Atlantic Books.

1984 Pigs for the Ancestors. Ritual in the Ecology of a New Guinea People. New Haven-London: Yale University Press (Revised and expanded edition).

Strecker, I.

1988 The Social Practice of Symbolization. An Anthropological Approach. LondonAtlantic Highlands: Athlone Press. 


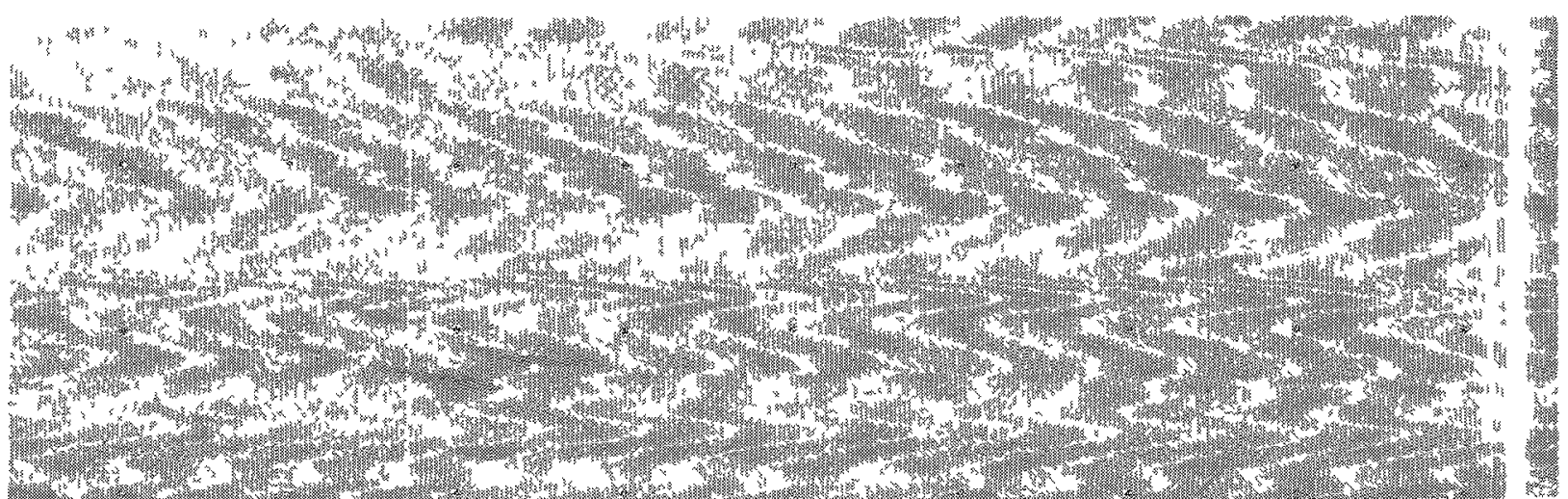

Tippett, A.R.

1970 Peoples of Southwest Ethiopia. South Pasadena: W. Carey Library.

Turnex, V.

1967 The Forest of Symbols. Ithaca-London: Cornell University Press.

1969 The Ritual Process. Chicago: Aldine.

1977 Process, system, and symbol: a new anthropological synthesis. Daedalus 106(3): 161-180. 


\section{Breaking and Making the State: The Dynamics of Ethnic Democracy in Ethiopia \\ (63)}

$32 / 21$

J. Abbink

$$
\begin{aligned}
& 3217 \\
& 324.1994 "
\end{aligned}
$$

\section{Introduction}

In the past four years, Ethiopia, as a state and as an idea, seems to have gone through a process of 'deconstruction'. In a political sense, the entity called 'Ethiopia' is under severe strain, and in an ideological sense, the idea of cohesion or unity of this old African state is more contested than ever. It is clear to see that traditional structures are being rethought and recast during the years of political experimentation and restructuring under the new transitional government since May 1991. In this process, the 'imagination' of Ethiopia becomes more and more difficult as well. This appears to be a deliberate effect of the new policy promoted by the present rulers. The background of this development is well known: the implosion of the communist-oriented regime of Mengistu Haile Mariam, which could not hold together in the face of the combined impact of years of mismanagement and internal decay and the cutting of its ideological and material support lines to the Soviet Union and other communist-bloc countries from late 1989. On 28 May 1991, the old government of the former Workers' Party of Ethiopia ${ }^{1}$ ignominously crumbled, a week after the flight of Mengistu Haile Mariam to Zimbabwe, to be replaced by a coalition of rebel forces, the Ethiopian Peoples' Revolutionary Democratic Front (EPRDF), with at its core the Tigray Peoples' Liberation Front (TPLF), originating from the northern highland region of Tigray. At the same moment, Eritrea, until then the most northern administrative region of Ethiopia, was taken over by the Eritrean Peoples' Liberation Front with the capture of Asmara, after a nearly 30-year-old civil war. (It has declared itself independent, after a referendum, on 25 May 1993).

Immediately after the capture of Addis Ababa by the EPRDF, carried out with American approval and encouragement on 28 May 1994, a 'National Conference of Peace and Reconciliation' was called in the capital. Many ethno-political liberation movements who had been active against the previous regime were invited (among them the Oromo Liberation Front, the Afar Liberation Front and the remnant of the Western Somali Liberation Front), and also several other very hastily set-up 'organisations'. ${ }^{2}$ But not all anti-Mengistu groups were welcome. Excluded, for instance, was the still existing Ethiopian Peoples' Revolutionary Party (EPRP), a formerly popular leftist political and guerilla movement which had fought a tough battle with Mengistu's regime in the late 1970s, but which was also an old rival of the TPLF. The conference led to the adoption of a national 
'Charter for the Transitional Period', to the installation of a transitional government, and of a non-elected 87-member Council of Representatives (COR). The Charter document ${ }^{3}$ was to be the supreme law of the country until a new constitution could be promulgated. It described the provisional new democratic order, including the prospect for elections, preparation of the constitution, press freedom, and freedom of movement and association. So far, we may see some parallel with democratisation movements in other African countries, such as Benin, Togo, or Malawi - although in Ethiopia, the discontinuity with the previous regime (the Dergue) is much more radical: the Transitional Government of Ethiopia (TGE) has dismantled not only the unity party and the government of Mengistu, but also replaced virtually all senior government personnel and reformed all state agencies and institutional structures. The former regime's military forces, close to half a million strong, were disbanded. There was never any doubt as to what group would dominate the TGE and the COR in the subsequent period and beyond: the military victors are the EPRDF, more particularly the TPLF. They had, while still fighting, already prepared their policy blueprints for Ethiopia after the take-over, and have been generally faithful to them ever since.

This article aims to give a dispassionate survey of the developments in Ethiopia since 1991, in order to assess some prospects of the experimental policy course followed by the new government.

\section{The Ethiopian Experiment and the Debate about Democrati- sation in Africa}

In the current debates on democratisation movements and the so-called era of 'mass-participation' in African politics, Ethiopia does not figure prominently. Nevertheless, the changes occurring there are of fundamental importance not only in the context of the country itself, but also in that of the larger region of the Horn of Africa. Ethiopia may indeed be, as its public image still suggests, 'different' from other African states (apart from Eritrea, it was never colonised, it has an approximately 2000 year-old state tradition in the highland area, as well as ancient literate traditions and indigenous forms of Christianity and Islam). But in many respects it is also a 'typical African society': with a heritage of underdevelopment and poverty, ecological and demographic problems, internal divisions, ethnic diversity, and a state marred by financial problems and corruption. ${ }^{4}$

Relatively little attention is paid by the Western media to developments in Ethiopia - for no direct Western interests are at stake — and there is minimal attempt to understand political and social developments from a more local perspective, or from a socto-cultural perspective. The consequent ignorance of most Westerners is compounded by the country's bewildering variety of political and/or liberation movements, and the confusing number of news magazines which, because written in Amharic, are relatively inaccessible to most foreigners. In addition, the government always has a public story or version of events which is specially tailored for 
Western (färänji) observers, and which may be quite different from versions known to the natives. Neither do Westerners attach any real urgency to the situation in Ethiopia, presumably because the communist regime has gone, the civil war has ended, the problem of Eritrea has been solved, and the proclamations and policies of the present TGE superficially indicate a steady course toward a democratic form of governance. Compared to the former government of Mengistu, much indeed has changed. However, the foundation of new power structures and of what is defined as democracy and accountability presently being prepared by the TGE deserves close scrutinity, with a long-term perspective, and with more attention to local constitutions of identity and nationhood in a historical and cultural sense. This paper will not address the latter theme in detail, but limit itself to a largely factual survey of recent trends.

\section{Assumptions and Outlines of the New Policy}

In recent years, the TGE has carried out a rhetorically and strategically very intelligent policy of restructuring the Ethiopian state and of delegitimising old leadership elites, mostly in ethnic terms. The policy measures have been gradual but decisive, and have led to far-reaching changes, intended to modify traditional frameworks of regional and 'ethnic' identity, and to replace old power holders, including experienced professionals and experts, from important positions all across the country, and to a politicisation of 'ethnic' difference even in remote corners of the countryside.

Notwithstanding the criticism generated mainly from within the country and from Ethiopian communities abroad, one has to acknowledge that the Ethiopian experiment in devolution of central state power to regions and of 'ethnicisation' of national politics can be characterised as unique in Africa, and that it has its negative as well as its positive points. ${ }^{5}$ The new authorities like to see it as an effort at internal 'de-colonisation', doing away with inequality and national oppression. The official programme is democratic restructuring of the country, enhancing 'real political participation of the masses' (especially the rural population), and ethno-regional rights for previously oppressed peoples or nationalities. Time and again, these elements are repeated in official discourse. The implication is that the idea of national unity or identity of Ethiopia, raised on a partly accidental amalgam of dozens of ethnic groups, should be rethought - not only politically but also ideologically. In this context, the EPRDF has not only devalued the Marxist narrative of national unity and development prevalent under the previous regime, but also continues to prevent any return to the idea of an integrating role for Ethiopian Orthodox Christianity (about 55 per cent of the population), as was claimed under Haile Selassie. There is now a policy of balancing it with Islam, so that neither can put its stamp on Ethiopian 'national identity'.

The underlying motive - and the rationale for the EPRDF/TPLF armed struggle in the past 20 years - was that of breaking the old socio-political order and the 
hegemony of what they saw as the 'Amhara' people (in particular, the Amhara from Shoa, the region around Addis Ababa), identified with the leading stratum under the previous two regimes, and over-represented in state administration, leadership positions, the professions, etc. In the background, the old historical rivalry between the Tigray and the Amhara (who are, however, strictly speaking neither a 'nationality' nor an 'ethnic group'; cf. Heran 1994; Takkele 1994, and the conflict was played out mainly on the level of their political elites: nobles and war-lords) plays a role, fed by a populist interpretation of certain historical events, like the crushing of the Weyyane rebellion in 1943 in Tigray and of the decadeslong neglect, e.g., in times of famine, of the Tigray region by the central government. ${ }^{6}$

The core ideological assumption of the EPRDF and thus of the TGE policy, has been that democracy can only be established through ethnicity, through regionally-defined ethnic rights. People are first and foremost members of a community: only as such can they realise their rights. The individualist model of representative aggregate democracy is abandoned in favour of a cantonised form. This idea is of course a logical result of the concept of 'national liberation' used by the TPLF and other ethnic organisations, which all emerged after the violent suppression of nation-wide, non-ethnic leftist revolutionary groups like EPLF and MEISON (the All-Ethiopia Socialist Movement). When these were crushed by the Mengistu government in the 'Red Terror' period (1977-79), many members of the defeated groups took the 'ethnic option', by returning to their home regions and starting again there to mobilise support. The ethno-regional factor was rhetorically and practically helpful in this mobilisation effort. The ethnic groups were all declared as having been 'oppressed' by the previous regimes and as deserving their rights (use of their own language, their own resources, more regional power, no more cultural hegemonism, etc.). The TPLF now submits that no country can be held together by force, but only by the free and voluntary choice of its peoples to stay together (the assumptions being that people primarily define themselves on the basis of 'ethnicity', that groups have well-defined borders, feel oppressed as a group and are or should be located in one region only).

While good as a battle cry, these principles have their own problems on the level of national state policy. It is one thing to declare the rights of ethnic communities, invariably called 'nationalities' in state discourse, but another to make them the units for a workable state policy. The predictable criticism of a large part of the Ethiopian public was: what about the mixture of groups, in regional distribution, in economic life, in marriage and descent, in preferred 'ethnic' identification? There may be no real solution for this except that of force.

The record of the TGE so far has shown a consistent elaboration of "ethnic policy'. It has its own problems and promises. ${ }^{7}$ The former Marxist ideology which the TPLF cherished up to six months before their take-over in May 1991 has been abandoned in favour of a more pragmatic outlook, especially in the economic sphere. In the political sphere, however, organisational principles de- 
rived from Leninism ('dual structures' of government and administration, democratic centralism, controlled media, a strong army for law-and-order purposes and as a pillar for the power structure) are seemingly still maintained, ${ }^{8}$ and the national policy of the EPRDF and TGE so far shows a remarkable continuity with the ideology and plans which the TPLF had when still fighting in the bush (cf. Markakis 1987:253-55).

\section{Results and Problems of the Ethiopian Experiment}

Some key issues to consider are the following:

- As the EPRDF model for the Ethiopian state is no longer of a unitary state, but of a loose federation of (ethno-)regions, one of the first things done by the TGE, and duly approved by the COR (in 1991), was to introduce a new regional map of Ethiopia, based on ethno-regions in each of which one ethnic group would have a clear (ideally an overwhelming) majority. There were 14 regions (called killil), among them Amhara, Afar, Oromia, Beni Shangul, Tigray, Somali, Sidama, and Kafa: all ethnic names. Preferably, people of 'foreign, non-indigenous' origins - especially of course the 'Amhara' immigrants or their descendants, pejoratively called neft'ennyas ('armed settlers') should not be there. Also all skilled and teaching jobs should be filled by locals, and not by 'immigrants'.

- Especially in the early years (1991-93), the politics of encouragement of ethnic rights and autonomy in the countryside led to a chaotic period of violent rivalry and power-struggle on the local level. In some areas, e.g., in Arussi, Harar, and Balé, it sometimes amounted to a campaign of 'ethnic cleansing', whereby 'non-natives' or 'neft'ennyas' were harrassed and their houses burnt down. Dozens of people were also chased away or killed. These actions were perhaps also thought of historically as a revenge of groups conquered in the time of Emperor Minilik II around the turn of the century, on the descendants of their conquerors. The role of EPRDF troops, supposed to keep law and order, was often not clear - they did not always prevent such massacres, but let the 'spontaneous process of conflict' run its course. The tactics of today have become less violent, but serve the same purpose. There are charges of intimidation and economic boycotting which have the same long-term effect of chasing people out of the regions where they were born and had jobs. In addition, there are still border conflicts between adjoining regions. For instance, people from Wälqait, an area in the former province of Gondar where Tigrinya is also spoken, objected to being included in the new expanded Tigray region. Several months ago they sent a delegation of elders to Addis Ababa to protest, but these were not heard but arrested. There are also cases of people who were assigned to one region, and who lost some of their land, who are now located in another region. 
- The politics of 'democratisation' are being tightly controlled by the EPRDF. They make the policy, get their proposals through the COR - which was not elected - and avoid substantial debate with minority groups in the COR or in the opposition. The COR is, generally speaking, not an autonomous law-making body (which it indeed by law cannot be). The minority parties, let alone the opposition, have no political leverage. For instance, the Oromo Liberation Front, in opting out of the TGE and the COR in July 1992 because of serious disagreements with the TPLF, has been neither prudent nor wise. ${ }^{9}$ It had 17 seats in the COR and some members in the Cabinet. In late 1994 there was talk of them returning and retaking their seats, but the reaction of the EPRDF was evasive. Hence whereas critics argue that the TGE as a transitional body should be attempting to implement a broad-based policy, especially when it envisages long-term policies and laws reshaping the face of the country, by either barring relevant opposition groups from the COR or the TGE, or by purposely marginalising them, or as a result of self-inflicted exclusion (OLF), the EPRDF reigns supreme and, according to several observers, increasingly autocratically (cf. Makau wa Mutua 1993b; 1994). As long as the EPRDF has the leading positions in the TGE, its political agenda will not be fundamentally influenced by other parties or social groups. This may, indeed, reflect its political weight, yet it is scarcely conducive to the democratic atmosphere which they claim to be creating in the country.

- While the TGE and EPRDF allowed the formation of political opposition parties under certain conditions, they have not been content to allow them to operate freely. Although these parties cannot be prevented or be legally disbanded if they have adopted the Charter and do not openly plead for violence, the TGE/EPRDF succeeds in harrassing them by means of intimidation by soldiers, by searching and vandalising their party premises and the homes of their adherents, or by arresting or kidnapping activists and leaders, or by taking them to court on dubious evidence. ${ }^{10}$ Not only AAPO (All-Amhara Peoples' Organization) and CAFPDE (Coalition of Alternative Forces for Peace and Democracy), but also OLF, EPRP and ONLF (Ogaden National Liberation Front) have been declared outcasts, and several members of these groups have been harrassed and detained without cogent charges.

In addition to this, the EPRDF has, since 1990, set up proxy parties directed at the various ethnic constituencies to compete with the above-mentioned, more rooted parties. These alternative parties, instigated by and allied to the EPRDF, are often recognisable by their name, ending in "Peoples' Democratic Organisation" (the so-called PDOs), e.g. WPDO (Wolayta), the HPDO (Hadiyya), and OPDO (Oromo Peoples' Democratic Organisation). It is said that the leadership of these PDOs is often made up of relatively unknown 'grassroots people' from the ethnic group in question, who have everything to gain from accepting a post under the EPRDF. ${ }^{11}$ The OPDO is of course meant to lure the Oromo away from the OLF, IFLO and other Oromo groups. The OPDO also functions as the party which produces cadres and administrators 
for the Oromia Region. Another good example is the ANDM (Amhara People's Democratic Movement, formerly EPDM) of the present Prime Minister Tamrat Layne and part of the EPRDF. It emerged from the EPRP in the late 1970s. It is now functioning as an alternative to the AAPO or for some constituent parties of the CAFPDE. Ethiopian and foreign observers seeing all this are not convinced that there is free competition of political groups in the country.

- The drafting of a new constitution, although announced as a democratic process whereby all the civilians would have a significant say, was dominated by the TGE and the commission it had appointed. Open discussions in the $k$ 'ebeles (the urban dwellers' associations and the peasants' associations) did not yield substantial changes, nor were they meant to. The meetings themselves were only visited by an estimated five per cent of the total population. Even so, they allowed for the voicing of serious criticism of the draft constitution, yet they made no significant impact upon the final text. Since the discussions started in the media and in the Constituent Assembly, the clauses on the land-lease law, on the 'right to secession' of disaffected ethno-regions and on some religious rights for Christians, proved controversial. But they were not rescinded or reformulated in the final version, approved in December 1994.

- There is a fear, in business classes and among the peasantry in many regions, that too much power for the various regions (differing substantially in population, resources, and wealth) will lead to internal conflicts, structural inequalities, and impediments for natural economic exchange, trade or employment opportunities. On the last point, for example, superfluous experts in one region will be seriously discouraged from working and living in another region where they do not 'ethnically belong'. The regions have to train their own manpower. This is already happening. The extra costs and the productive years lost with this policy need not be emphasised.

- In connection with the foregoing, there is deep scepticism about the new educational policies of the TGE. In many rural areas, even in Oromo country, peasants are worried about the policy of teaching school children in the local language (many dozens in the various regions) instead of in Amharic, which is still the lingua franca. They may agree with the use of their language for literacy - which goes faster in the local language - but not for administrative purposes, 'cutting off' their region from the wider whole. Their argument is interesting: they say, against the self-appointed ethnic leaders of the PDOs and other 'liberation groups', that it is of little use to learn the language they already know at home also in the schools: the challenge is to learn another language, one used nationwide, and on that account more important, in order to enable their children to advance and perhaps escape the poor lives they live in their own region. Amharic is still one vehicle for this and is still the most widespread language in the country. The language policy (not mentioning the substantial practical problems and the costs of translating and/or preparing teaching materials in all the languages) has also led to local rivalries between 
certain 'language groups' if the 'dialect' of one language within a related group (e.g. Omotic) is taken as the standard for minority groups. Education will also politicise ethno-regional identity and de-emphasise an idea of national identity - which may be one of the underlying purposes of the policy in the first place.

- An important but less tangible change occurring in Ethiopian society today is the elbowing out of the old educated strata and, what some observers call, the 'Tigrayarisation' of the power structure. Irrespective of age, experience or job qualifications, many leading positions in the state machinery, the public services, the economy, the decision-making centres from the national to the local level, are given to people of Tigray background. This seems to be a fairly consistent trend, meant to install a new and young generation of loyal people who owe their promotion and jobs to the EPRDF. Such favouritism has been commented upon as a typical trait of African politics in general (cf. Bayart 1993, especially chapter nine).

- Another notable fact is that EPRDF-cadres and army units in most of the country form a kind of dual administration. Acting behind the 'democratically chosen' local administrators, they are suspect for many local residents. Similarly, the police force is being instructed by these units behind the scenes, and cannot act independently in maintaining the law. These local officials ultimately are accountable to and dependent (for their jobs) on the EPRDF representatives.

As a result of nearly four years of transitional policy, the face of Ethiopia and of its society has already changed substantially. Economically, there is a more open market-oriented economy, which has eased conditions for economic activity but has not yet led to an upsurge of significant, durable economic growth or an increase in living standards. Ethiopia has been led to adopt a Structural Adjustment Programme, with predictable social problems emerging. ${ }^{12}$ There are many people being dismissed from government service, and the growing number of beggars in the capital is one indication of the continuing general misery. In the rural areas, there is land scarcity due to returning ex-soldiers, excessive population growth and continuing degeneration of the land, to which the government's answers are slow in coming and difficult to implement. Several highly important nation-wide economic schemes are faltering. ${ }^{13}$ The middle classes (businessmen, professionals, teachers, or traders, forming a stratum of diffuse ethnic origins) are not overly happy with the ethnic policies which they fear may artificially increase group boundaries and regional and 'ethnic identities': in these circles, which never thought in strict terms of ethnicity, it is said that for business, social mobility and development it would be better for Ethiopia to have a unitary structure instead of a federation of autonomous ethno-regions with their own economic, licensing and tax regimes.

In terms of ethnic self-identification, the TGE/EPRDF has succeeded in making ethnicity or 'nationality' an ever-present, and often highly emotional, issue in 
the minds of Ethiopians. The formerly mainly culturally expressed sense of ethnicity, and enacted in religion, life-cycle rituals, festivals, second language use, etc., has now been politicised to such a degree that it has become an ideology of opposition and exclusion. Obviously not all groups regret this: the OLF and the ONLF and the new intellectual cadre of minority ethnic groups, for instance, encourage ethnic consciousness in all respects, not objecting to the essentially divisive function of this ideology. They say that a new 'Habesha hegemonism' in Ethiopia, this time not of Amhara but of Tigray, should be avoided. Other groups like the Gurage, Wolayta or Dorze (with many members dispersed all over the country) do not see the big advantages of ethnic autonomism. All agree, however, that national policy so far has been too much of a one-group affair, and that the basis for political decision-making in this transitional period should be broadened. But opposition appeals to this effect have always been neglected or rejected by the president and the government. ${ }^{14}$

Politically speaking, decentralisation and ethnicisation of the regions is well under way. The core of regional (killil) governments has been established. In elections, the new policy would also mean that no group can get a majority beyond its own region, due to the system of region-level elections at one remove. Even in ideal procedural circumstances, non-ethnic parties would not be allowed or would stand no chance of winning such elections.

\section{Elections}

On 5 June 1994, elections for a 'Constituent Assembly' were held. They formed a conspicuous index to gauge the process of top-down 'democratisation' in the country. The election process illustrated the measure of power monopoly and skillful manoeuvering of the present government. The occasion of the elections did not solve the dilemmas of 'ethnic' politics, but confirmed all the core traits of the new political thinking and the new democratic centralist structure of 'powerdistribution' in the country via the new regions. The elections were very well prepared. In the 14 regions, candidates for the 548-seat Constituent Assembly were to be elected, under the auspices of the National Electoral Board of Ethiopia (set up in 1993 and accountable to the COR and the TGE.) The job of the Constituent Assembly was to discuss, amend and approve the draft constitution prepared in the first half of 1994 by a special commission appointed by the TGE and led by the law expert Kifle Wodajo. ${ }^{15}$ The legitimacy of the draft was contested by all parties not represented in the Council of Representatives, as well as by large sections of the Ethiopian people.

The Constituent Assembly elections were the second round of nation-wide elections organised by the TGE. In June 1992, local elections (for zones and districts) had been held, already based on the new regional map of the country. ${ }^{16}$ The purpose then had been to elect local administrators (often through new local ethnic parties) and to legitimise the Transitional Government, in which the 
EPRDF were the main power. The 1992 elections were strongly dominated by the EPRDF, and the organisation was such that in virtually all places the EPRDFsponsored candidates were elected, some critics saying that the presence of the EPRDF army (the former guerilla army which after the 1991 victory functioned as a temporary national army), was in itself a factor conducive to this. In some districts, there were no party candidates at all, so that EPRDF candidates were elected by default. According to the largely negative reports of international observers (cf. National Democratic Institute - African-American Institute 1992), the failure of this event was due to several factors: a lack of material facilities and preparation, a voter-public not educated in election procedures, the impossibility of many voters knowing what candidates were standing and for what, and in many places, a campaign of open or covert intimidation and violence, often by (pro-) EPRDF groups. Subsequent eye-witness reports from the countryside have confirmed this negative image. Due to pre-election pressure and alleged 'undemocratic' manoeuvering of the TGE, some groups, like the OLF, boycotted the elections, after already having left the TGE and the Council shortly before that.

The Constituent Assembly elections of June 1994 were much improved in technical planning and execution, but again the dominance of the EPRDF behind the scenes was notable. Again, the main opposition groups (OLF, AAPO, CAFPDE, and a southern peoples coalition) were absent because of their own boycott. Their line was (and is) that a policy of consensus, announced in 1991 for the transitional period, had been circumvented by the power-monopolising strategy of the EPRDF, which refused to broaden the base of the TGE and the decision-making structures. Also there were charges of intimidation by government troops and activists, and of biased screening of candidates (registered through the government-controlled local k'ebeles or local authorities). There were candidates from several remanning officially-allowed parties and organisations as well as 'independent' candidates (many connected to a party, and to the EPRDF).

Voters had to register before the elections. The percentage of people who did so, varied from region to region: from 44 per cent (in Harar) to 96.5 per cent (in Tigray). In Addis Ababa (Region 14), 53 per cent of the eligible voters registered.

The results of the low-key but largely peaceful election did not come as a surprise: in the overwhelming majority of the electoral constituencies EPRDF candidates, or candidates supported by this coalition (TPLF-ANDM-OPDO), won. Turn-out was reasonably good, although in many areas people were pressured to vote through their k'ebeles in order not to lose some rights to buying cheap products like sugar and cooking oil. In the countryside the psychological dominance of pro-EPRDF candidates (often already holding official posts) as well as the pressure to 'vote correctly' was again such that one could perhaps not really speak of fully free and fair elections. A general problem was the lack of suitable candidates, partly because of the boycott by many opposition parties. 
One interesting aspect of this 1994 round of elections was that ethnic groups with a membership of below 100000 (the size of a constituency) automatically received a seat in the Constituent Assembly, because they might otherwise have been outvoted by the majority in their region. In this way, 22 groups each got a free seat, especially from the south and west of the country (including some groups which have never seen Addis Ababa or never really dealt with the central government). Ipso facto, their representatives can probably largely be seen as EPRDF-supporters.

A second interesting aspect was that a number of independent and oppositional candidates were nevertheless elected, despite their programmes not always being clear, and their links with existing parties being obscure. The eventual outcome was that EPRDF won 484 of the 548 seats (excluding the assigned ones). Curiously enough, virtually all the seats in the Oromia and the Amhara regions (most opposed to government policies) were also won by the EPRDF: 289 of the total of 294 were taken by ANDM and OPDO. In Addis Ababa, where more than half of the eligible voters did not vote, 13 of the 23 seats were won by the EPRDF, and eight by independent candidates. This was the lowest score for the EPRDF.

Before the elections, the organised opposition had manoeuvred itself into a Catch22 situation: to participate would have meant to recognise the legitimacy of the EPRDF government and the electoral process; to opt out meant marginalisation and losing any chance of national leverage or power-sharing. The EPRDF had counted on this, and - in view of the predictable reactions of Western observers and donors to non-participation of the opposition - took the credit.

In the sessions of the Constituent Assembly - which did not replace the Council of Representatives - as well as in the regional governments, the TGE could thus count on loyal support for the constitutional draft, and for its effort to federalise the country. The Constituent Assembly was active for about three or four months, and duly approved the constitution on December 8, 1994. The Council of Representatives and the TGE then confirmed it. The next stage of the "transition process' is that of national parliamentary elections, scheduled for May 1995, which are being prepared by the National Electoral Board. The 'transitional period' will be extended again to allow the TGE and the EPRDF to lead the process in the right direction'. If, as is to be expected, the political parties for these next elections are required to have an 'ethnic identity' basis, and are denied the right to campaign nation-wide (i.e. are not permitted to register in other than their 'home regions'), then the outcome will again be a foregone conclusion.

Negotiations in Washington DC in early 1995 between members of the TGE and the main opposition groups such as AAPO, CAFPDE and OLF on a proposed rapprochement and on participation of these groups in the May elections have not led to clear results. 


\section{Prospects of the 'Ethnic State'}

The 'revolutionary-democratic' reform policy of the TGE/EPRDF in the past four years has been directed at the consolidation of power and at strict implementation of its own agenda of 'democratisation' along ethnic lines. The process is controlled from above, keeping the political process, party formation, opposition activities and the independent press under tight surveillance. The old programme of ethnic 'federalisation' of the country continues, employing the law-making process in the COR, and using educational policy and economic devolution and restructuring. Thus a political structure of counter-balancing regions, with none strong enough to dominate the country, is being aimed at, ideologically buttressed by supposedly self-evident collective 'ethnic identities'. The long-term role of the centre, the Ethiopian state, is still in doubt, but political and economic conditions and considerations make it clear that it cannot simply 'wither away' (Eshetu 1994:25).

It can be concluded that popular expectations among the Ethiopian public in May 1991 about the prospects for democratisation, political freedom and quick economic upsurge were too extravagant. Perhaps it was chimerical to think that the TGE would create a viable and broadly accepted political order on the smoking scrap-heaps of Mengistu's Ethiopia. The chaos and the heritage of 17 years of mismanagement and destruction were too much to correct in so short a period. But whatever the reasons, the feelings of disappointment in the country are widespread. The paradoxical policy of ethnicisation and EPRDF-hegemonism, the lack of visible economic progress, the manipulations of the democratic order, and the widespread security problems, create an atmosphere of irritation and fear for the future.

It is also possible that within the EPRDF, there is no ultimate clarity about the question of ethnicity and national cohesion. The EPRDF itself has problems with the notion of complete secession of disaffected groups from the country, judging, for example, from its reactions to the course of the OLF and the ONLF. Cynical minds say that the EPRDF is at this juncture opposed to full secession only for as long as their home area Tigray is not strong enough to stand on its own feet. But it is more likely that the EPRDF and President Meles Zenawi have seen that, apart from domestic problems, the 'ethnic formula' also has its drawbacks in terms of international policy in the Horn. In the future, small political units may not be strong enough to withstand emerging pressures from neighbouring countries such as Sudan, Kenya, a reconstituted Somalia and perhaps even Egypt (the Blue Nile question). Also, in Ethiopia, in contrast with, for instance, Zaire, the state is still a coveted resource to capture, as well as an enduring entity forged by 2000 years of history. In the group around President Meles, there thus may be a new notion of the potentially central role which a politically and economically strong Ethiopia can play in (the Horn of) Africa. Part of this notion is a minimal-idea of national unity. The core preoccupation dominating their policy is simply not to allow any ethno-hegemonism, especially not of the 'Amhara'. A new 'ethnic state', i.e. one 
based on ethnic entities, may not have a solid future. Furthermore, if the EPRDF were to succeed in establishing such a state, under its own largely Tigray leadership, it might well repeat the model of the past (the Shoan 'Amhara' state which it so resented) and undermine its own existence in the long run, because Tigrayans are a numerical minority of approximately 10 per cent of the population. Unifying tendencies - historically speaking, led but not monopolised by the diffuse ethnolinguistic group called Amhara - cannot be denied and fighting them in the form of the Shoan Amhara may prove to be tilting against a windmill.

As for the domestic democratisation process, it is perhaps true that no African country has as yet found a lasting solution. Ethiopia, which, like any other country on the continent, has its problems, cannot be expected to out-perform the others, despite the fact that the preconditions there are still much better than in most other countries: there is no anti-colonialist inferiority complex, there is a long state tradition with inclusivist elements, and there is a strong idea of independence, national political identity and pride. The solution must be sought in the development of a new form of 'dual identity': ethno-cultural, and national-political. This would mean that, provided the political and economic conditions for multiple identification are there, representativeness and economic opportunity must lead to new forms of mutual cooperation and national cohesion. For this purpose, it would be required that on legal and administrative grounds, ethnicity in itself should have no instrumental advantage. Obviously, this would also imply a reshuffling of the regional boundaries in the long run, and a lifting of all impediments to the free flow of people across regional boundaries, as the 'market' demands, and a de-ermphasis of the 'ethnic discourse' in the country. However, this is a utopian scenario, and it is unlikely that the present, in formal terms rather 'reactionary', policy will soon be changed. The primacy of politics above economics is still a dominant principle in Ethiopia. The ethno-political reform policy may also have retarding effects on national and regional economic development. In the African context in general, the dilemma of ethnicisation (rights based on a collective 'identity') or democratisation (rights based on the individual) demands an imaginative solution. While there are still promising aspects, it is uncertain whether or not Ethiopia can provide such a solution.

\section{List of Acronyms and Notes}

\section{AAPO All-Amhara Peoples' Organisation \\ ANDM Amhara Peoples' Democratic Movement \\ CAFPDE Coalition of Alternative Forces for Peace and Democracy \\ COR Charter for the Transitional Period \\ EPDM Ethiopian Peoples' Democratic Movement, now APDM}

EPRDF Ethiopian Peoples' Revolutionary Democratic Front. The EPRDF is the name for a front of three groups dominated by the Tigrean Peoples' Liberation Front. The EPRDF is - since 1989 - a political party, but is also and mainly a guerilla force. As a guerilla force, largely consisting of Tigrayan people with some Amhara, Oromo, and others, the EPRDF came to power in May 1991, and indeed their fighting force became the national army: the army replacing that of Mengistu and taking over all responsibility for the maintenance of law and order. 


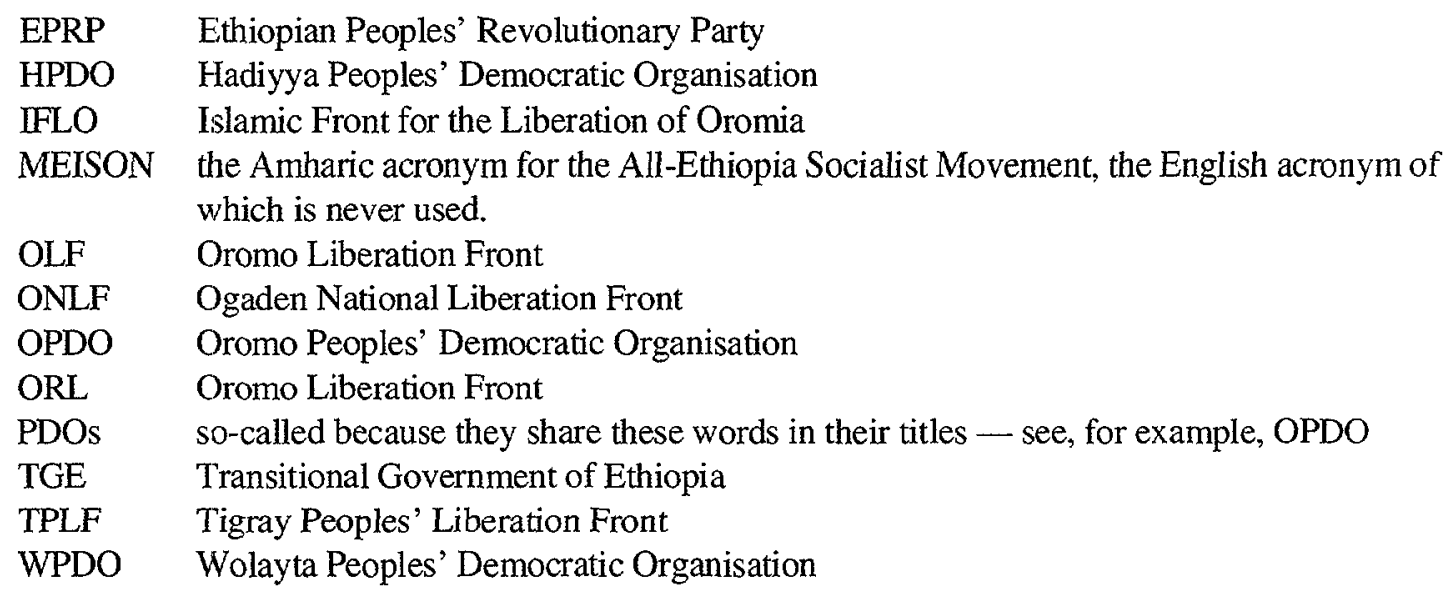

1. In May 1990, renamed the 'Ethiopian Democratic Unity Party' as part of a belated move toward a programme of liberalisation and a 'mixed economy' by a sinking regime.

2. Including the 'Omotic' delegation (there is no such people, only a language group of that name), the Issa and Gurgura Peoples' Movement (Somali), and a Gurage delegation, the 'leader' of which was only invited to participate on the very eve of that conference, by telephone.

3. For the text, see: Negarit Gazeta (Addis Ababa), Vol.50, No.1, 22 July 1991.

4. Although by far not on the scale of other African countries like Zaire or Nigeria or Kenya.

5. Cases of contrast would be Kenya under Moi - against open ethnic policy - and Uganda under Museveni, where another original experiment of democracy (a 'nion-party system') has been in progress.

6. The remarkable fact that the EPRDF received substantial support from the local Manz-Amhara population in their march on Addis Ababa, during its last and crucial offensive in Northern Shoa in early 1991 , is being forgotten.

7. For a severely negative judgement, see Makau wa Mutua (a Harvard lawyer), 1993a; 1993b; 1994.

8. The core of the TPLF/EPRDF in terms of leadership, personal networks and ideological thinking is the group formerly called the Marxist-Leninist League of Tigray. It was renamed in early 1994, cancelling the Marxist-Leninist reference.

9. Other critical members, individually or as a group, were removed from the COR, e.g. the SEPDC (a coalition of southern peoples) when it participated in an alternative Conference of Peace and Reconciliation of opposition groups in Paris in late 1994.

10. A serious case was the condemnation, on 27 June 1994, of the popular leader of the AAPO, Asrat Woldeyes, a medical professor of 65, to two years' imprisonment on account of having planned 'violent attacks on the government'. According to Amnesty International (1 July 1994), the evidence was extremely flimsy, and not acceptable to a court of law. This sentence means that the chairman of AAPO will not be in the running when the national parliamentary elections are held in 1995. In December 1994, he received an additional three years' sentence, again on charges few people understood.

11. For a near complete list of PDO names, see the Ethiopian Herald (Addis Ababa), June 5, 1994, p.7.

12. In the latest IMF Survey (23 January 1995, pp. 17-19), Ethiopia is praised for its economic policy.

13. One example: the big and ambitious afforestation project between Addis Abab and Bahir dar, started under the previous regime, has collapsed due to bickering between the two new regions (Killils 3 and 4).

14. Incidentally, a typical trait of Ethiopian political culture: power attained with the force of arms is not given away.

15. A survivor, once active in the governments of Haile Sellassie and of Mengistu.

16. Registering and voting was on the basis of ethnic identification, cf. McDonald, S. 1992.:29. 


\section{References}

Bayart, J. 1993. The State in Africa: the Politics of the Belly. London, New York: Longman.

Eshetu, C. 1994. "Opening Pandora's Box: Preliminary Notes on Fiscal Decentralisation in Contemporary Ethiopia", Northeast African Studies 1,1(New Series):3-27.

Heran S. 1994. "Ethiopia: A Historical Consideration of Amhara Ethnicity." In Marcus, 1994:742-73.

Makau wa Mutua. 1993a. "The New Oligarchy", Africa Report, (September-October 1993):27-31. 1993):50-2.

1993b. "An Oppressed Opposition", Africa Report (November-December

1994. "The Anointed Leadership", Africa Report, (November-December 1994):31-4.

Marcus, H. (ed.) 1994. New Trends in Ethiopian Studies, 2 volumes. Lawrenceville, N.J.: Red Sea Press.

Markakis, J. 1987. National and Class Conflict in the Horn of Africa. Cambridge: Cambridge University Press.

McDonald, S. 1992. “Learning a Lesson”, Africa Report, September-October 1992:29.

National Democratic Institute - African-American Institute 1992. An Evaluation of the June 21, 1992 Elections in Ethiopia. Washington - New York: NDI - AAI.

Takkele Taddese, 1994. "Do the Amhara Exist as a Distinct Ethnic Group?" In Marcus, 1994:168-87. 